\title{
WHICH KRAFT OF STATUTORY INTERPRETATION? A SUPREME COURT OF CANADA TRILOGY ON INTEllectual PROPERTy LAW ${ }^{1}$
}

\author{
CAMERON J. HUTCHISON*
}

The techniques used by courts to interpret statutes can be characterized as inconsistent, and at times, excessive. Current methodologies of statutory interpretation often reflect deeply normative views about the appropriate institutional role of the legislative and judicial branches of law-making, but this characterization of the debate is misleading. Rather, the problem lies with properly discerning legislative meaning and intent in full awareness of the limitations and possibilities of statutes as communicative devices. The author suggests a new methodology of statutory interpretation, whereby courts analogize the facts before them with certain paradigm cases. This methodology serves to constrain judicial discretion and enables courts to fill gaps in legislation in connection with novel cases.
Les techniques que les tribunaux utilisent pour interpréter les lois peuvent se caractériser comme étant inégales et parfois excessives. Bien que la caractérisation du débat soit trompeuse, les méthodes actuelles d'interprétation des lois traduisent souvent des opinions très normatives sur le rôle institutionnel approprié des pouvoirs législatif et judiciaire relativement à la confection des lois. Le problème relève plutôt de la difficulté à bien discerner le sens et l'esprit de la loi tout en étant parfaitement conscient des limites et des possibilités des lois en tant que mesures de communication. L'auteur propose une nouvelle méthode qui permettrait aux tribunaux de faire l'analogie des faits devant eux avec certaines causes servant de modèle de référence. Cette méthode limite la discrétion judicaire et permet aux tribunaux de combler les écarts dans la législation en ce qui concerne les nouvelles causes.

\section{TABLE OF CONTENTS}

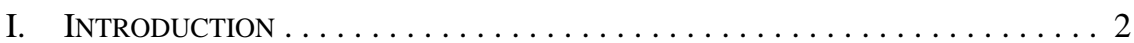

II. TRADITIONAL MODELS OF STATUTORY INTERPRETATION $\ldots \ldots \ldots \ldots \ldots .4$

A. Formalism AND THE Literal APPROACH $\ldots \ldots \ldots \ldots \ldots \ldots \ldots$

B. PurPosive ANALYSIS $\ldots \ldots \ldots \ldots \ldots \ldots \ldots \ldots \ldots \ldots \ldots \ldots \ldots \ldots \ldots$

C. ApPLICATION $\ldots \ldots \ldots \ldots \ldots \ldots \ldots \ldots \ldots \ldots \ldots \ldots$

III. THEORETICAL UNDERSTANDING OF STATUTES

AND THEIR INTERPRETATION $\ldots \ldots \ldots \ldots \ldots \ldots \ldots \ldots \ldots \ldots \ldots \ldots$

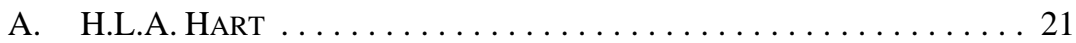

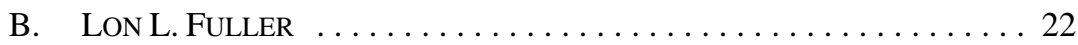

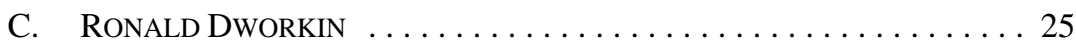

D. REED DICKERSON ....................... 27

Assistant Professor, Faculty of Law, University of Alberta. Thanks are due to my research assistant, Wassila Semaine. I very much appreciate the helpful comments of James Muir and Stephen F. Ross to an earlier version of this work. All errors are mine.

1 The title is a reference to Euro-Excellence v. Kraft Canada, 2007 SCC 37, [2007] 3 S.C.R. 20 [Kraft], which is one of the trilogy of cases discussed in this article. Most notably, in Kraft, Bastarache J. denied copyright protection for chocolate bar logos, which he deemed more properly the domain of trademark law. The problem was that relevant legislation seemed to permit concurrent copyright and trademark protection. Was this judicial hocus pocus to achieve the right policy result or is there a manner in which we may understand the interpretation of statutes such that this is a principled outcome? While this article is broader in scope than the Kraft decision, the methodology of statutory interpretation outlined herein suggests that Bastarache J.’s dissenting opinion was not inconsistent with legislative intent. 


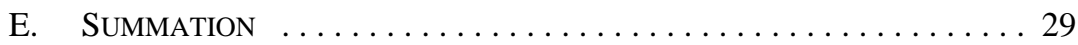

IV. A METHODOLOGY OF STATUTORY INTERPRETATION . . . . . . . . . . . . . . 30

A. InSTITUTIONAL LEGITIMACY AND COMPETENCY . . . . . . . . . . 30

B. Statutes as Communicative Devices $\ldots \ldots \ldots \ldots \ldots \ldots$

C. A Methodology of StATUtORy InterPRETATION . . . . . . . . . . 33

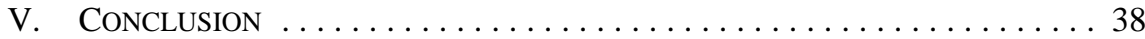

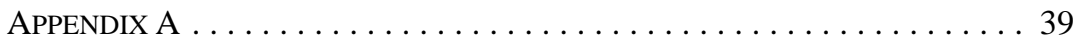

\section{INTRODUCTION}

Statutory interpretation often appears as artistry in which techniques are employed, whether by counsel or by judges, to achieve desired outcomes. ${ }^{2}$ A casual encounter with most texts on the subject reveals an arsenal of tools upon which counsel may construct opposing legal arguments. Those searching for a consistent methodology of statutory interpretation by the judiciary, whether in a string of cases concerning a given area of law, by a particular court, or even by a single judge, will often be disappointed. In extreme cases, courts may be criticized for either "judicial activism," when an interpretation is perceived to exceed the language of a statute, or giving effect to an absurd interpretation, when literal wording is strictly followed. While lawyers and legal academics accept that the judicial function (that is, applying statutory language to resolve specific disputes) is necessarily interpretive, disagreements abound concerning the appropriate scope of discretion.

Methodologies of statutory interpretation reflect deeply normative views about the appropriate institutional role of the legislative and judicial branches in the enterprise of creating law, on the one hand, and interpreting it to resolve specific disputes, on the other. For the most part, the debate is falsely characterized along institutional lines. Few dispute the principle of legislative supremacy such that judges should give effect to statutory meaning. Rather, the problem lies in properly discerning legislative meaning and intent in full awareness of the limitations and possibilities of statutes as communicative devices.

Superficially, statutes are threadbare vessels of communication. They attempt to regulate complex areas of human activity with relative linguistic brevity. Rules may be vaguely worded so as to encompass, in an abstract sense, a broad range of subject matter. Moreover, statutes are drafted prospectively and in view of paradigmatically conceived scenarios, that is, typical kinds of foreseeable cases that might arise. It follows that statutory meaning will often be uncertain or incomplete in the face of novel cases, that is, the kinds of cases not foreseen by the legislature and for which, consequently, there is no reasonably clear interpretation flowing from the statute. Still, linguistic minimalism and prospectivity need not be fatal to robust interpretations of statutory language provided an appropriate analytical framework is in place.

2 Judges, of course, would never characterize statutory interpretation in this way. See e.g. Stephen F. Ross, “The Location and Limits of Dynamic Statutory Interpretation in Modern Judicial Reasoning," online: (2002) Issues in Legal Scholarship Dynamic Statutory Interpretation 6 at $1<$ http://www.bepress. com/ils/iss3/art6/> [footnotes omitted, emphasis added]: "judges rarely admit that they are following any particular approach to interpretation. Rather, they tend to reach an appropriate result using some internal mode of reasoning and then write the strongest possible opinion, invoking arguments that may have been irrelevant to their own decision.” 
Presumptions are often employed by courts to flesh out and maximize statutory meaning. At the most general level, these consist of presumptions that the legislature acts meaningfully and precisely when it chooses language and adopts a schematic framework within the statute. We may further enhance statutory meaning when we recognize that linguistic devices such as vague language represent a delegation of interpretive function from the legislature to the judiciary. A further presumption, which I advance in this article, is that statutory language should be understood as addressing only that which we may say was reasonably anticipated by the legislature.

In other words, judges should first determine whether the facts before them fit within statutory rules, as they presume those rules were paradigmatically conceived by the legislature. Judges may be guided in this endeavour by analogizing the facts before them with paradigm cases, that is, typical cases captured by a rule as manifested either in the statute, prior case law, or as elicited by subjective connotations in the mind of the judge arising from a purposive analysis of the statute. Specifically, courts should determine if there are enough material similarities between paradigm cases and the case before it, to include it under the statutory rule. Using our analogical reasoning abilities as lawyers, this methodology allows us to supplement bare statutory language with richer meaning in accordance with legislative intent.

Analogizing against paradigm cases is an appropriate heuristic for gauging legislative intent and serves to constrain, as well as enable, the principled development of statutory meaning. It constrains judicial discretion such that reasonably clear statutory meaning as applied to non-novel cases should be honoured by courts. The method also enables courts to fill gaps in legislation in connection with novel cases for which there is an absence of direct legislative intent. Here, courts may develop statutory meaning by considering statutory purposes, principles of law, and external context. This approach to statutory interpretation, of course, does not deny the supremacy of the legislature to create the law, only that there are inherent limitations in their ability to do so prospectively.

The structure of the article is as follows. In Part II, I present traditional approaches to statutory interpretation, namely literal and purposive methodologies. A trilogy of intellectual property law cases recently handed down by the Supreme Court of Canada (Théberge v. Galerie d'Art du Petit Champlain, ${ }^{3}$ Kirkbi AG v. Ritvik Holdings, ${ }^{4}$ and Kraft, ${ }^{5}$ (the trilogy)) will be analyzed from these perspectives. Appropriately in my view, Canadian courts usually apply a purposive analysis to interpret statutes. As the trilogy shows, however, this analysis is often performed in an undisciplined, and therefore inconsistent, fashion. In Part III, I present theoretical understandings of statutes and their interpretation, namely the writings of H.L.A. Hart, Lon Fuller, Ronald Dworkin, and Reed Dickerson. The interpretive dilemmas of the trilogy will be analyzed from the perspective of these theories. In Part IV, I construct the argument advanced above and return to the trilogy once again to show how my suggested methodology of statutory interpretation would resolve the interpretive dilemmas. 


\section{Traditional Models OF StATUtORY INTERPRETATION}

There are various rules of thumb used by courts to interpret statutes. Perhaps simplistically, I have placed general judicial attitudes to statutory interpretation under the categories of literal and purposive approaches. ${ }^{6}$ These attitudes reflect deeper normative views about the possibility of statutory language communicating meaning and, concomitantly, the proper institutional role of the court. After describing these approaches, I will briefly discuss some main criticisms of each. I then present the trilogy, honing in on the main interpretive dilemma in each case, as well as explaining the methodology used by members of the court to resolve the case.

\section{A. FORMALISM AND THE LITERAL APPROACH}

Formalism holds that statutory rules come from the legislature "pre-formed" and are to be mechanically applied by courts to resolve specific disputes. ${ }^{7}$ Formalism is a tenet of the liberal conception of the rule of law, which postulates that the legislature, as a democratically elected body, should create the rules, and judges, as unelected officials, are merely to apply them to resolve particular cases. As such, formalism is thought to reflect a legitimate separation between the political and judicial branches. The perceived certainty and stability of rules befit other liberal rule of law values, that is, government in accordance with clear rules to: curb arbitrary power, protect the rights and liberties of individuals, and maximize personal autonomy such that individuals can predict when government will interfere in their lives. $^{8}$

A corollary of formalism is the literal approach to statutory interpretation. ${ }^{9}$ A strictly literal approach holds that courts give effect to the literal meaning of words "even if the consequences of that decision seem either to frustrate the purpose behind those words or to

In their purest form, these approaches are quite distinct, though there is a degree of overlap, e.g., there may be little difference between the application of a purposive analysis or the golden rule in a given case. Interestingly, it appears civil law countries engage in the same general debate about interpretive approaches. See e.g. Winfried Brugger, "Legal Interpretation, Schools of Jurisprudence, and Anthropology: Some Remarks From a German Point of View” (1994) 42 Am. J. Com. L. 395 at 396-97:

In ... grammatical interpretation, philological methods are used to analyze the meaning of a particular word or sentence. In systematic interpretation, one attempts to clarify the meaning of a legal provision by reading it in conjunction with other, related provisions of the same section, or title, of the legal text, or even other texts within or outside of the given legal system; thus, this method relies upon the unity, or at least the consistency, of the legal world. In historical analysis, the interpreter attempts to identify what the founders of a legal document wanted to regulate when they used certain words and sentences.... In teleological analysis, the ... [other three elements] are only deemed indicative, not determinative, of the contemporaneous purpose of the legal provision or document.

Stephen Bottomley \& Simon Bronitt, Law in Context, 3d ed. (Sydney: Federation Press, 2006) at 70 [emphasis in original]: "[t]he basic idea behind legal formalism is that it is possible to learn and apply the law as if it were a self-contained system."

$8 \quad$ Ibid. at 60.

$9 \quad$ The literal approach is also known as the "plain meaning approach.” See e.g. Ruth Sullivan, Sullivan and Driedger on the Construction of Statutes, 4th ed. (Vancouver: Butterworths Canada, 2002) at 9: When the language of the statute seems clear and unambiguous, courts in both Canada and the United States have adopted a plain meaning approach, which eschews reliance on the context of the statute as a whole, its purpose, or extrinsic aids. 
diverge significantly from what the decisionmaker thinks — the rule aside — should be done."10 The assumption here is that it is possible for language to be clear and to possess a "true meaning." 11 Formalism merges with a strictly literal approach in the sense that the plain language of a statute, shorn of other considerations, "self-applies" to determine the result of specific cases.

There are less strict variants of the literal rule, which either recognize the futility of uncovering a clear rule in all instances, or at least acknowledge the possibility that otherwise clear language may frustrate the purpose of the legislation. These literalists may look to the purpose or intent of the legislation to ascertain meaning. ${ }^{12}$ The golden rule, for example, allows a court to modify an otherwise plain meaning leading to an absurd result. ${ }^{13}$ Another variant, propounded by Antonin Scalia, argues that words have a limited range of meaning, which courts should interpret in an objective sense at the time of the statute's enactment. ${ }^{14}$ Scalia rejects recourse to legislative history to uncover meaning, ${ }^{15}$ as well as absurd interpretations that can result from a strictly literal construction of statutes. ${ }^{16}$ Like all formalists, Scalia also rejects the possibility of statutory language evolving in meaning but instead bases interpretation on an original understanding of a statute's words. ${ }^{17}$

While common in the United States, Canadian courts typically eschew strictly literal interpretations — and for good reason! Language rarely conveys one true meaning; even less is it capable of self-application. Even when we are able to pin down a reasonably precise connotation, a determination of the outer fringes of meaning of a word still requires interpretive effort. We will see in Théberge, for example, that it is entirely unclear whether changing the substrate of authorized reproductions infringed a copyright holder's right to "produce or reproduce” his work. In such cases, liberal rule of law virtues of certainty and

$10 \quad$ Frederick Schauer, “Formalism” (1988) 97 Yale L.J. 509 at 538.

11 However, see e.g. Aharon Barak, The Judge in a Democracy (Princeton: Princeton University Press, 2006) at 123: "There is no pre-exegetic understanding of a text, for we can only access and understand it through an interpretive process." Further at 150: “Text becomes clear only at the end of the interpretive process. As long as the purpose of the text has not been realized, the text is unclear.” Ibid. at 149. See also William N. Eskridge, Jr., Philip P. Frickey \& Elizabeth Garrett, Legislation and Statutory Interpretation, 2d ed. (New York: Foundation Press, 2006) at 231-38: In the U.S., there is a soft plain meaning rule where the plain meaning can be overcome by evidence of legislative intent to the contrary, or the harder version which looks only at text-based or text-linked sources.

$13 \quad$ Supra note 9 at 237.

14 Antonin Scalia, A Matter of Interpretation: Federal Courts and the Law (Princeton: Princeton University Press, 1997) at 23-24. As such, he suggests it is the language which is promulgated rather than what the law-makers meant as interpreted through legislative history that should determine meaning (at 17). On original meaning as opposed to current meaning, he makes these comments in connection with constitutional interpretation (at 38). Ibid. at 32.

$16 \quad$ Ibid. at 23-24. Scalia criticizes, as an example of strict construction, the majority holding in Smith $v$. United States, 508 U.S. 223 (11th Cir. 1993) wherein the accused was found guilty under a statutory provision that stated "uses ... a firearm.” The gun was "used” not for violent purposes but as barter for drugs (at 223).

$17 \quad$ Supra note 4 at 38. 
predictability may be more illusory than real. ${ }^{18}$ Finally, the literal approach disables rather than enables courts from achieving "the optimal result based on all relevant factors." 19

\section{B. Purposive Analysis}

Richer and more complex conceptions of statutory interpretation tend to prevail in Canadian courts. Under a purposive analysis, ordinary language is central to the inquiry of statutory meaning, though it is informed by context, scheme, and purpose, as well as legislative intent. This approach is best captured in the Driedger principle which is often referenced by Canadian courts:

[T] he words of an Act are to be read in their entire context, in their grammatical and ordinary sense harmoniously with the scheme of the Act, the object of the Act, and the intention of Parliament. ${ }^{20}$

In contrast to a literal approach, the Driedger principle acknowledges that the many possible meanings of words are best resolved by looking to context, scheme, purpose, and intent. ${ }^{21}$ The principle does not deny that words may have an ordinary meaning ("the natural meaning which appears when the provision is simply read through" ${ }^{22}$ ), only that this meaning must be measured against these other considerations. ${ }^{23}$ Should the ordinary meaning run counter to the purpose of the legislation or its scheme, for example, the court may construe an interpretation to give effect to the latter. ${ }^{24}$

Let us now look at these "other considerations" that inform ordinary meaning. Context, according to Driedger, is multifaceted in that it includes the literary context (the immediate context and the Act as a whole including its scheme), legal context (substantive law), and external context (how the legislation works in the real world). More precisely, the immediate context consists of the provision in which the words appear, closely related provisions, as well as the entire statute as amended. ${ }^{25}$ The legal context refers to extant substantive law that may shed light on legislative intent, comprising of the statute book as a whole including related legislation, relevant case law, the common law, and international law. ${ }^{26}$ External

Supra note 11 at 150: "The decision of whether the text is clear or not is made on the basis of feeling. Each judge has his own feeling.... The same applies to the question of whether the clear text leads to an absurd result. What one judge sees as absurd, another sees as a reasonable result.” Still, the literal approach, by narrowing a range of interpretive options, offers more rule stability than the purposive approach.

Supra note 10 at 542 . The negative connotation often associated with formalism is that, in applying rules mechanically, a decision-maker ignores relevant factors that would otherwise be taken into account. Supra note 9 at 1, citing Elmer A. Driedger, The Construction of Statutes (Toronto: Butterworths, 1974) at 67. The fourth edition of the Sullivan text reverts to the Elmer Driedger approach as stated in the second edition and reproduced above. Curiously, the third edition altered the approach. See Haida Nation v. British Columbia (Minister of Forests) (1997), 153 D.L.R. (4th) 1 (B.C.C.A.) at paras. 8-13, for a discussion of the difference between the second and third edition formulations of the rule. Sullivan, ibid. at 18.

22 Ibid. at 21, citing Canadian Pacific Air Lines Ltd. v. Canadian Air Line Pilots Association, [1993] 3 S.C.R. 724 at 735 .

Ibid. at 20.

Ibid.

Ibid. at 261 .

Ibid. at 261-62. 
context is concerned with the "setting in which the [enacted] law ... currently operates."27 The assumption is that legislation "[i]s a response to circumstances in the real world and it necessarily operates within an evolving set of institutions, relationships and cultural assumptions."28

The scheme of the Act refers to meaning to be gleaned from "how the provisions or parts of the Act work together to give effect to a plausible and coherent plan." ${ }^{29}$ We may infer meaning of a provision in light of this overall plan. More broadly, according to the principle

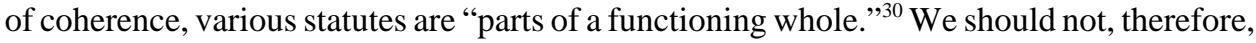
expect that the legislature has promulgated laws that conflict with one another. The "object of the Act" refers to its purpose, that is, legislation is presumed to have a discoverable purpose, which should be furthered, or at least not defeated, by a given interpretation. ${ }^{31}$ Purpose goes to both the Act as a whole and the specific provision. ${ }^{32}$ The purpose of an Act may be stated in the preamble, though more typically, it is divined through judicial interpretation.

Legislative intent may be conceived in a specific sense, that is, what was the specific intention of this provision or statute as revealed by the law-makers themselves, or in a purposive sense, that is, what mischief in general terms was the legislature concerned with remedying. ${ }^{33}$ Statutory interpretation in the U.S. places much emphasis on specific intent and thus, countless hours are spent sifting through debates and comments of the law-makers. In Canada, courts have generally eschewed specific intent, preferring to glean legislative intent objectively from the language, scheme, and/or purpose of the Act. ${ }^{34}$ As such, legislative intent may merge with a purposive analysis. Furthermore, legislative intent (or purpose) is usually conceived in historical terms, though interpretation is not necessarily limited to that which was known at the time of enactment. ${ }^{35}$

Ibid. at 260 .

Ibid. at 260-61.

Ibid. at 284.

Ibid. at 168 .

Ibid. at 195.

Ibid. at 195-96. Sullivan takes pains to emphasize, however, that a purposive analysis, i.e., purpose as one factor of consideration, and not a purposive approach, i.e., purpose as the primary consideration, is the preferred methodology (at 199).

33 Eskridge, Jr., Frickey \& Garrett, supra note 12 at 221-30. The authors explain at length the nuances (and difficulties) of different "intentionalist” approaches, namely specific intent (what did the legislators actually have in mind?); imaginative reconstruction (how would those legislators have dealt with this issue if they had thought about it?); and purposive intent (what general intent did the legislators have?). "As the inquiry becomes steadily more abstracted from specific intent, however, not only does its democratic legitimacy fade, but the inquiry becomes less determinate and perhaps more driven by nonlegislator value choices, hence in tension with the rule of law” (at 222).

Supra note 9 at $1-2$.

More commonly than not, legislative intention is conceived in a historical and static sense, i.e., what was the intention of Parliament at the time the law was enacted. This originalist approach is predicated on the assumptions "(1) that a statute has only one true meaning, and (2) that this meaning cannot change in response to changing social conditions”: Randal N. Graham, Statutory Interpretation: Theory and Practice (Toronto: Emond Montgomery, 2001) at 4. However, critics of originalism posit that legislation is drafted in "broad and uncertain terms" that only acquires its meaning through application to specific fact situations (at 13). A dynamic approach, by contrast, "permits the interpreter to select a construction that fits with current needs and departs from historical expectations" (at 31). Examples of these competing approaches (originalism and dynamism) are offered in the Harvard College v. Canada 
A purposive analysis acknowledges that the meaning of language is imprecise and measures words against contextual, schematic, and purposive considerations. As such, the approach avoids the shortcomings of the literal approach, namely absurd interpretations or those that appear to run counter the purpose and functioning of the legislative regime. ${ }^{36}$ But purposive analysis is not an interpretive panacea. For example, ascertaining a statute's purpose is not straightforward. In the absence of a preamble, how does a judge determine the purpose of a particular statute ${ }^{37}$ If there is more than one purpose, and two of which conflict, how can this approach resolve the controversy? Even if there is a single purpose, is it "too general and malleable to yield interpretative closure in specific cases[?]"38 More broadly, the range of considerations open to the court increases the scope of interpretive outcomes, leading to less certainty and stability of statutory meaning. As we will see in Théberge, the Copyright Act's ${ }^{39}$ purpose is divined by the majority opinion as a balance between competing interests which, rather mysteriously, is understood on the facts of that case to narrow a copyright holder's rights in favour of those other interests in play.

\section{ApPlication}

\section{INTELLECTUAL PROPERTY LAW}

Intellectual property law ${ }^{40}$ gives the creators of intangibles (for example, the expressive elements of a book, the idea behind an invention) monopoly rights as a means of protecting their efforts and investment against free-riding appropriation through imitation and copying. The Supreme Court of Canada has identified the purposes of each of copyright, patent, and trademark protection. To ensure the encouragement of, and just rewards for, creative expressions, copyright provides legal protection to authors of original expressive works, be they music, art, photographs, architectural designs, or countless others. ${ }^{41}$ A patent grants exclusive rights to owners of inventions that are useful, ingenious, and novel, thereby offering an incentive to disclose the workings of invention in the goal of technological progress. ${ }^{42}$ Trademarks protect source-identifying features of products and services so that consumers are not misled as to the origins of a product or service. ${ }^{43}$ Each of these forms of intellectual property protection give rise to unique monopoly rights that vary in scope, term,

(Commissioner of Patents), 2002 SCC 76, [2002] 4 S.C.R. 45. In that case, the majority refused to include life forms under the definition of invention (as a "composition of matter") since biotechnology was not known at the time that the Act respecting Patents of Invention, S.C. 1869, c. 11, was promulgated. The dissent, however, considered the purpose of the statute to be the encouragement of innovation and presumes that inventions will include unforeseen creations such as biotechnology. Eskridge, Jr., Frickey \& Garrett, supra note 12 at 229: "Purposivism attempts to achieve the democratic legitimacy of other intentionalist theories in a way that renders statutory interpretation adaptable to new circumstances.... Potentially, this kind of theory reconciles democracy, the rule of law, and practical efficacy."

Ibid. at 230: Attributing a purpose may "implicate political and policy considerations better suited to the branches that are democratically accountable.”

Ibid.

R.S.C. 1985, c. C-42 [CA].

Here, I refer only to copyright, trademark, and patent law.

Supra note 3 at para. 30. See quote reproduced at infra note 47 and accompanying text.

Free World Trust v. Électro Santé, 2000 SCC 66, [2000] 2 S.C.R. 1024.

Mattel v. 3894207 Canada, 2006 SCC 22, [2006] 1 S.C.R. 772. 
and permissible exceptions. These basic features and functions of intellectual property are quite distinct.

It sometimes arises that a single intangible is eligible for more than one form of intellectual property protection. For example, a computer program may have expressive elements, such as literal aspects of source codes or display features that are original and qualify for copyright while also having functional elements that are sufficiently ingenious to make it eligible for patent protection. ${ }^{44}$ A product qua product that is distinctive in design may act to identify the source of the ware while also being ingenious in its functional features to qualify for patent protection. ${ }^{45}$ Or a design logo may be both original and expressive, while also serving to identify the source of a product or service. ${ }^{46}$ It is also likely in all of the examples mentioned above, that concurrent (or overlapping) intellectual property protection will result in consecutive (or extended) protection. Thus, once monopoly rights cease for one form of protection, for example, the 20-year patent expires, another form of intellectual property protection persists or is granted which extends a monopoly, for example, a copyright term of the life of author plus 50 years.

The cases discussed below focus on statutory interpretation issues, which either determine the scope of monopoly protection (Théberge) or the permissibility of concurrent intellectual property protection (Kirkbi and Kraft). The cases will be presented in the following manner: after a brief description of the facts, the analysis will hone in on the main interpretive issue(s). This will be followed by a discussion of the nature of the interpretive dilemma presented and how, using the traditional interpretive approaches discussed above, individual judges resolved it.

\section{THÉBERGE V. GALERIE D’ART DU PETIT CHAMPLAIN}

Copyright gives the author of an original expressive work, for example, expression in a book, the exclusive right to produce the work in another derivative form, such as producing the book into a movie, and making copies in both its original and derivate form(s). Mr. Théberge, a renowned Quebec artist, brought this action for copyright infringement against subsequent assignees of a contract authorizing poster copies of his paintings. The original assignment, to which Théberge was a party, provided:

The product is offered for sale without restriction as to use, i.e. it may be framed, laminated or combined with other products and such uses shall not be considered to have generated products or sub-products other than those provided for in this contract. ${ }^{47}$

The issue in this case was whether the transfer of the poster painting from a paper to canvas substrate by the subsequent assignees constituted a production or reproduction and thus

Div.))

45 See e.g. supra note 4, discussed in Part II.C.3, below.

$46 \quad$ Supra note 1.

$47 \quad$ Supra note 3 at para. 13. The court refers to this transfer as an assignment, although the sale of authorized reproductions appears more in the nature of a licence. 
infringed copyright. Significantly, this process did not involve the creation of new copies, only the transfer of ink from one substrate (paper) to another (canvas).

\section{a. Right to Produce or Reproduce the Work}

Section 3(1) of the CA sets out the rights of an owner of a copyright as including: "the sole right to produce or reproduce the work or any substantial part thereof in any material form whatever." 48 Justice Binnie, for a slim majority of four, held that infringement based on the right to produce or reproduce did not arise on these facts. There was no independent right of production under the $C A$, according to the majority, ${ }^{49}$ thus rendering this language essentially superfluous. The focus of the decision was on whether or not the right to reproduce was infringed. Here, the majority reasoned that the transfer to a new substrate did not constitute infringement because there was no reproduction, that is, no new copies were made. Put simply, copyright infringement requires the act of unauthorized copying..$^{50}$ Even the act of making a derivate work - say taking the artistic drawing of a cartoon character and making a doll out of it - involves a reproduction of "new copies or manifestations of the work," according to this analysis. ${ }^{51}$

The purpose of the $C A$, as determined by the majority, essentially dictated this result:

The Copyright Act is usually presented as a balance between promoting the public interest in the encouragement and dissemination of works of the arts and intellect and obtaining a just reward for the creator (or, more accurately, to prevent someone other than the creator from appropriating whatever benefits may be generated). ${ }^{52}$

Emphasizing this need for balance between creator rights and user rights, the majority interpreted the right of a creator narrowly. Justice Binnie asked: “[b]ut in what way has the legitimate economic interest of the copyright holder been infringed? The process began with a single poster and ended with a single poster."53

Justice Gonthier, speaking for a minority of three, interpreted s. 3 quite differently. In his view, "reproduce" did not necessarily imply an increase in the number of copies. ${ }^{54}$ In addition, the language of s. 3 of the $C A$, that is, "in any material form whatever," suggested rematerializing that which already existed in a "first, original material form." 55 Thus, "[f]ixation of the work in a new medium is therefore the fundamental element of the act of

Supra note 39 [emphasis added].

Supra note 3 at para. 48.

Ibid. at para. 42.

Ibid. at para. 49 [emphasis in original]. In obiter, Binnie J. at para. 41 commented: that "a change of substrate could, as part of a more extensive set of changes, amount to a reproduction in a new form (perhaps, for example, if the respondent's work were incorporated by the ink transfer method into some other artist's original work) but the present case does not rise to that level.” This example seems to engage the production right (i.e., a derivate work) and not the reproduction right, which Binnie J. claims must involve the making of copies.

Ibid. at para. 30 .

Ibid. at para. 38 [emphasis added].

Ibid. at para. 139. Justice Gonthier relies on a dictionary definition of the term, which does, in fact, refer to copying.

Ibid. at para. 146 . 
'reproduc[ing] ... in any material form whatever." "56 The s. 3 right of reproduction is therefore engaged by changing the poster substrate.

Furthermore, Gonthier J. held that Théberge did not dispose of this medium right (that is, changing the substrate) by way of assignment. Section 13(4) provides as follows:

\begin{abstract}
The owner of the copyright in any work may assign the right, either wholly or partially, and either generally or subject to limitations relating to territory, medium or sector of the market or other limitations relating to the scope of the assignment, and either for the whole term of the copyright or for any other part thereof, and may grant any interest in the right by license, but no assignment or grant is valid unless it is in writing signed by the owner of the right in respect of which the assignment or grant is made, or by the owner's duly authorized agent. ${ }^{57}$
\end{abstract}

This section makes it clear that a copyright holder retains the residue of copyrights that are not explicitly assigned away in writing: that which is not assigned, in other words, remains with the copyright holder. ${ }^{58}$ The language of the assignment in this case, that is, "sale without restriction as to use," referred to the paper substrate product and did not include a right to change the medium. ${ }^{59}$ As well, the specifications in the assignment "i.e. it may be framed, laminated or combined with other products" restricted the use of the paper product and did not extend to changing the medium altogether. ${ }^{60}$

\title{
b. Nature of the Interpretive Dilemma
}

The interpretive dilemma that confronted the Court in Théberge was whether the act of changing the substrate of authorized poster reproductions constituted infringement of the owner's right to produce or reproduce the work. This case is an excellent example of the shortcomings of the literal method. There is no indication in these general terms whether changing the background of authorized reproductions of a work engages either right. The case challenged the Court to determine the fringes of meaning associated with this bare expression of rights.

To resolve this interpretive dilemma, Binnie J. interpreted the language with reference to the statute's purpose, as he conceived it. The need to balance creator rights with user rights, in his opinion, justified the reading down of the rights of a copyright holder. Specifically, the "legitimate economic interests" of the copyright holder were not impacted by the subsequent assignee's changing of the substrate. There was no statutory basis for Binnie J.'s attribution of the CA's purpose, even less so that this should shrink rather than expand the copyright holder's rights in this case. Using statutory purpose to resolve an interpretive ambiguity was, to put it mildly, rather inexact. The concept of legitimate economic rights, as we will see, was invoked by Bastarache J. in Kraft. Importantly, the concept emerged here as a judicial refinement of the legislative purpose needed to resolve the unclear application of statutory language to a novel case.

\footnotetext{
$56 \quad$ Ibid. at para. 147 [emphasis in original].

$57 \quad$ Ibid. at para. 163 [emphasis in original], citing CA, supra note 39.

58 Théberge, ibid.

$59 \quad$ Ibid. at para. 176.

$60 \quad$ Ibid. at para. 177.
} 
Justice Gonthier's analysis gleaned meaning from the context of the statute. However, this analysis was no more definitive in resolving the issue. That the s. 3 language of "in any material form whatever" engaged the reproduction right was not entirely convincing. It is just as plausible that this language implies the making of copies in any material form. A more convincing argument would be to connect the right to produce with "in any material form whatever.” Even then, it remains unclear whether the changing of substrate rises to the level of first production of a derivate work. ${ }^{61}$

\section{KIRKBI AG V. RITVIK HOLDINGS.}

Lego blocks are plastic, rectangular blocks with eight studs protruding on top and eight slots on the bottom into which studs from another block fit. These blocks are combined such that various structures can be created by children. In 1988, the last of the Lego block patents, owned by Kirkbi AG, expired in Canada. ${ }^{62}$ Thereafter, Kirkbi AG attempted to register the blocks as a distinguishing guise trademark but the application was unsuccessful. The issue in this case focused on whether the Lego block qua block was nonetheless an unregistered trademark eligible for protection under the common law tort of passing off and its statutory iteration in s. 7(b) of the Trade-marks Act. ${ }^{63}$

To understand the case, a brief review of the statutory scheme and relevant provisions of the TMA is necessary. A trademark protects consumers and businesses alike by identifying the source of a product. Trademarks usually take the form of a distinctive logo or brand name associated with goods or services. At the time of sale, a trademark that appears on the wares themselves or on the packaging and which serves to distinguish the product from others in the marketplace, is entitled to trademark protection under the $T M A \cdot{ }^{64} \mathrm{~A}$ trademark may also include a distinguishing guise which includes the "shaping of wares or their containers" or "a mode of wrapping or packaging wares" whose appearance is used to distinguish the product from those sold by others. ${ }^{65}$

Registered trademarks enjoy enhanced rights of protection under the Act, while those for unregistered trademarks are limited. A registered trademark holder is entitled to bring an action for infringement against another's unauthorized use of an identical or confusingly similar mark, and to protect the goodwill of the mark (ss. 19, 20, and 22). ${ }^{66}$ The primary advantages of registering a mark are that it entitles the holder to a broader scope of rights and

Justice Gonthier referred to the medium rights of a copyright holder under s. 13(4), but curiously, did not use this right to extend his contextual analysis of s. 3. His understanding of "medium" included the substrate of poster reproductions, though again, it is unclear whether changing the substrate rises to the level of a new medium.

Supra note 4 at para. 4.

R.S.C. 1985 , c. T-13 [TMA].

Ibid., s. 4(1): "A trade-mark is deemed to be used in association with wares if, at the time of the transfer of property in or possession of the wares, in the normal course of trade, it is marked on the wares themselves or on the packages in which they are distributed or it is in any other manner so associated with the wares that notice of the association is then given to the person to whom the property or possession is transferred." Time of transfer includes all points in the distribution change and is not limited to ultimate sale to the consumer: see e.g. Lin Trading v. CBM Kabushiki Kaisha, [1989] 1 F.C. 620 (C.A.). 
infringement is easier to prove. By contrast, the holder of an unregistered mark is limited to an action for passing off, which is more difficult to prove legally. ${ }^{67}$ Both registered and unregistered marks may persist for as long as there is commercial use as a trademark. ${ }^{68}$ The Court was faced with whether a monopoly in the block itself could be extended, perhaps indefinitely, as an unregistered trademark.

Justice LeBel, for the Court, delivered the judgment. His decision began with the following discussion of the distinct purposes of the separate regimes of intellectual property protection:

\begin{abstract}
The vast and expanding domain of the law of intellectual property is going through a period of major and rapid changes. The pressures of globalization and technological change challenge its institutions, its classifications and sometimes settled doctrines.... Jurisprudence attempts to address — sometimes with difficulty - the consequences of these broad social and economic trends. The state of patent law is evidence enough of the stresses on the process of jurisprudential development in a world where statute law itself struggles to catch up with the life of laboratories and markets.... The economic value of intellectual property rights arouses the imagination and litigiousness of rights holders in their search for continuing protection of what they view as their rightful property. Such a search carries with it the risk of discarding basic and necessary distinctions between different forms of intellectual property and their legal and economic functions. $^{69}$
\end{abstract}

The Court emphasized that this case was about whether a trademark subsisting in an offpatent product would be "consistent with the nature of marks and the underlying policies which structure intellectual property law."70

\title{
a. Does Functionality Apply to Unregistered Trademarks?
}

The central issue in this case was whether an unregistered trademark may subsist in a product whose features are both functional and distinguishing. According to the Court, the doctrine of functionality maintains that trademark law could not be used to protect the utilitarian features of a distinguishing guise. In other words, "trade-marks law is not intended to prevent the competitive use of utilitarian features of products, but ... fulfills a sourcedistinguishing function." 71

The problem is that the statutory basis for the doctrine of functionality pertains only to registered trademarks, as stated in s. 13(2): "No registration of a distinguishing guise

Ibid. at paras. 62-69: The three necessary elements of a passing off action are: "the existence of goodwill, deception of the public due to a misrepresentation and actual or potential damage to a plaintiff” (at para. 66, citing Ciba-Geigy Canada Ltd. v. Apotex, [1992] 3 S.C.R. 120). Proving infringement of a registered mark requires the plaintiff to show use of an identical or confusingly similar mark: TMA, supra note 63 , ss. 19-20. 
interferes with the use of any utilitarian feature embodied in the distinguishing guise."72 The limited scope of this provision, that is, registered marks only, is affirmed by a prior statute which made reference to functionality in the definition of distinguishing guise, thus suggesting its application to both registered and unregistered trademarks. ${ }^{73}$ Why was the legislation amended to reference functionality to registered marks only? The Court did not satisfactorily answer this question but merely accepted that the functionality doctrine applied to all trademarks, based on precedent (which created functionality without a statutory basis $)^{74}$ and policy:

The changes in the drafting of the statute did not signal any intention to remove a doctrine of long standing, with the strange result that unregistered marks might have been granted broader protection than marks registered under the Trade-marks Act. ${ }^{75}$

\section{b. Nature of the Interpretive Dilemma}

The interpretive dilemma here is that a relatively straightforward statutory scheme of rights and remedies for each registered and unregistered trademark leads to a seemingly strange result: the ability to protect as an unregistered trademark that which is prohibited as a registered trademark. A plausible, but not convincing, argument can be posited that unregistered trademarks possess weaker rights (compared with registered marks) thus justifying a wider scope of available subject matter. In the Court's opinion, however, there appeared no good reason to protect as an unregistered mark that which is not eligible for registration. The purpose of the TMA, which is to protect only source-identifying features of all marks, is used to override the relatively clear differential scheme of rights. In this regard, the Court appears swayed by the fact that the guise was formerly under patent. The Court suggests that the trademark regime should not be used to extend the monopoly of subject matter properly the domain of patent law.

TMA, supra note 63 [emphasis added]. Sections 13(1)(a) and (b) requires that the guise be distinctive and prohibits registration of a guise which is "likely unreasonably to limit the development of any art or industry."

73 Unfair Competition Act, S.C. 1932, c. 38, s. 2(d): a distinguishing guise as independent "of any element of utility or convenience it may have." It is a canon of statutory interpretation that amendments to a statute are deemed meaningful. There is no other meaningful explanation for restricting the limitation to registered marks only other than an intention that the restriction no longer applied to unregistered marks.

$74 \quad$ Remington Rand Corp. v. Philips Electronics N.V., (1995) 64 C.P.R. (3d) 467 at 471: "It is common ground, and was so stated by the Trial Judge, that the invalidity of a trade mark registration on the basis of functionality has no express statutory basis and has to be found in the case law, beginning with Imperial Tobacco Company of Canada, Limited v. Registrar of Trade Marks.” Further at 478: “A mark which goes beyond distinguishing the wares of its owner to the functional structure of the wares themselves is transgressing the legitimate bounds of a trade mark.” In the only two prior cases that address functionality where an unregistered trademark is asserted, courts have come to different results. In Thomas \& Betts, Ltd. v. Paunduit Corp., [2000] 3 F.C. 3 (C.A.), the Federal Court of Appeal dismissed the passing off action on the basis that the unregistered mark was functional. In Hermes Canada Inc. v. Park, 2004 BCSC 1694, 37 C.P.R. (4th) 244, however, the Court found that a passing off action could be maintained notwithstanding that the mark was rejected for registration on the basis of functionality.

$75 \quad$ Supra note 4 at para. 60. 
The decision in Kirkbi is a good example of how the Driedger principle, in its totality, may pull in different directions: one may remain faithful to the wording and the scheme of the statute or judicially amend it according to the statute's purpose. In some quarters, judicial amendment of sloppy legislative drafting is defensible on the basis of avoiding absurd results. However, as I will argue in Part IV, the institutional role of the legislature is to carefully draft legislation that avoids these kinds of foreseeable problems.

The analytical starting point in Kirkbi is a statement of purpose underlying regimes of intellectual property protection as well as external context, that is, specific regimes of intellectual property rights (IPRs) serve distinct functions (the separation principle) which are challenged by both technological changes and efforts by rights holders to extend monopolies. Once again, as in Théberge, we see the articulation of a broader rationale of IPR protection, that is, the separation principle, based on purposive considerations. This separation principle, along with the concept of legitimate economic rights, is used by Bastarache J. to support his opinion in Kraft.

\section{EURO-EXCELLENCE V. KRAFT CANADA}

Kraft Foods Belgium (KFB) and Kraft Foods Schweiz AG (KFS) were the manufacturers of Côte d'Or and Toblerone chocolate bars, respectively. Kraft Canada (KCI) was the exclusive distributor of these chocolate bars in Canada. The Canadian copyright in Côte d'Or and Toblerone logos as artistic works were licensed to KCI on an exclusive basis. Prior to 2000-2001, Euro-Excellence was the authorized distributor of Côte d'Or and Toblerone chocolate bars but, when that role fell to KCI, continued to import and sell the chocolate bars in Canada. Since Euro-Excellence sold chocolate bars that were packaged in wrappers with the same logos for which KCI held the Canadian copyright, the issue was whether the company was liable for secondary infringement under s. 27(2) of the $C A .^{76}$ Two sub-issues which arose from this situation were: (1) whether trademark and copyright protection could both subsist in the logos; and (2) the nature of the transfer of the territorial copyright interest to KCI.

a. Does Section 64(3) of the Copyright Act Permit

Concurrent Protection of the Logos?

The CA gives ostensible recognition of the possibility of concurrent protection of a work as a copyright and trademark under s. 64(3), which provides:

Subsection (2) does not apply in respect of the copyright or moral rights in an artistic work in so far as the work is used as or for...

Supra note 39. As the logos denoted the proper source of the goods, trademark law was not in issue. See Smith \& Nephew Inc. v. Glen Oak Inc., [1996] 3 F.C. 565 (C.A.), where the Federal Court of Appeal held, on the facts of that case at para. 14 [emphasis added]: "Smith \& Nephew as Canadian licensee and importer of goods bearing BDF's trade marks cannot complain of the sale in Canada of other goods which are also manufactured by or under license from BDF and bear the same trade marks. There can be no deception as to the origin of the goods, which are exactly what they purport to be." 
(b) a trade-mark or a representation thereof of a label. ${ }^{77}$

This recognition awkwardly appears as an exception to a provision (s. 64(2)) which permits infringement of works for which copyright and industrial design protection subsists. For a majority of the Court represented by the judgments of Rothstein and Abella JJ., s. 64(3) settled the matter. Justice Bastarache, however, read down this provision on the facts of the case.

Justice Bastarache denied the application of copyright to the chocolate bar wrappers claiming that they were "incidental works" not worthy of protection under the CA. Justice Bastarache's analysis of the purpose of copyright protection emphasized recent jurisprudence of the Supreme Court, which limited the rights of copyright owners. Citing Théberge, Bastarache J. advanced that copyright protection was limited to "legitimate economic interests" of the copyright holder. ${ }^{78} \mathrm{He}$ also drew attention to the "separation principle" advanced in Kirkbi, that is, "basic and necessary distinctions between different forms of intellectual property and their legal and economic functions." ${ }^{\text {,79 }}$ Furthermore, Bastarache J. cited the statutory interpretation principle of statutes in pari materia, meaning that the $C A$ should not only be internally coherent but "must also not be interpreted in a fashion which is inconsistent with the Trade-marks Act." ${ }^{80}$ Whereas trademark law "protects market share in commercial goods; copyright protects the economic gains resulting from an exercise of skill and judgment.”81

In light of the purpose of copyright protection and the limitations pertaining thereto, Bastarache J. read into the CA a concept of "incidental works" which denied a claim of copyright infringement under s. 27(2):

[I]f a work of skill and judgment (such as a logo) is attached to some other consumer good (such as a chocolate bar), the economic gains associated with the sale of the consumer good must not be mistakenly viewed as the legitimate economic interests of the copyright holder of the logo that are protected by the law of copyright. $^{82}$

In other words, the $C A$ does not permit copyright holders to assert their rights to prevent cheaper imports into the country since the logo or work is "merely incidental to their value as consumer goods.” ${ }^{33}$ Justice Bastarache did not suggest that copyright and trademark could

CA, supra note 39.

Kraft, supra note 1 at para. 76. At para. 79, Bastarache J. also cites CCH Canadian Ltd. v. Law Society of Upper Canada, 2004 SCC 13, [2004] 1 S.C.R. 339, which emphasized the centrality of user rights in the scheme of copyright, thus underscoring the need to protect only the legitimate economic rights of the copyright holder.

Kraft, ibid. at para. 82, quoting Kirkbi, supra note 4, LeBel J.

Kraft, ibid. at para. 83 [citation omitted]. On statutes in pari materia, see supra note 9 at 324: "[s]tatutes enacted by a legislature that deal with the same subject are presumed to be drafted with one another in mind, so as to offer a coherent and consistent treatment of the subject.” It is questionable, however, whether the intellectual property statutes in question deal with "the same subject matter."

Kraft, ibid.

Ibid. at para. 85.

Ibid. at para. 86. Justice Bastarache acknowledges that a determination of when a work is merely "incidental" will not always be easy, at para. 94: "Some factors which may be useful in making such a determination could include the nature of the product, the nature of the protected work and the 
not co-exist, but "that different forms of intellectual property protect different types of economic interests." ${ }^{84}$ To give effect to copyright protection here would extend copyright beyond its justifying rationale of just rewards, and permit it "to be leveraged far beyond the use intended by Parliament, allowing rights to be artificially enlarged into protection over consumer goods. ${ }^{85}$ Justice Bastarache was explicit in limiting the doctrine of incidental works to s. $27(2)$ only. ${ }^{86}$

The judgments of Rothstein and Abella JJ., representing a majority of the Court, rejected Bastarache J.'s “incidental works” approach to copyright law, adamant that there was no statutory basis for this interpretation. ${ }^{87}$ In Rothstein J.'s view, a copyright subsisted on the basis of originality (that is, skill and judgment) of an expressive work and no distinction was made between incidental and non-incidental works. Moreover, the Court's holding in Théberge, which emphasized the "legitimate economic interests" of a copyright holder, did not support a reading down of the $C A$ with respect to the scope of protection for covered works. On the contrary, s. 64 of the Act permitted concurrent copyright and trademark protection, in his opinion. ${ }^{88}$

Nor did the Court's holding in Kirkbi, according to Rothstein J., lend support to a reading down of copyright protection since the doctrine of functionality which denied trademark protection to utilitarian features of a product, more properly the subject of patent law, had a statutory basis. ${ }^{89}$ Justice Rothstein, on the one hand, affirmed the principle declared by LeBel J. in Kirkbi that there are "basic and necessary distinctions between different forms of intellectual property and their legal and economic functions" ${ }^{\text {90 }}$ but, on the other hand, qualified this principle where Parliament had provided otherwise. Justice Rothstein did not,

relationship of the work to the product. If a reasonable consumer undertaking a commercial transaction does not think that the copyrighted work is what she is buying or dealing with, it is likely that the work is merely incidental to the consumer good.” At para. 95, he offers the example of a small logo on a shirt (incidental) and a reproduction of a painting on another shirt (protected).

Ibid. at para. 87.

Ibid. at para. 88 .

Ibid. at para. 95.

Ibid. at para. 4. At paras. 110-11, Abella J. agrees with Rothstein J. that copyright protection extends to all eligible works and that there is no statutory basis for not protecting "incidental works" under s. 27(2). Moreover, she expresses concern over the uncertainty pertaining to a doctrine of "incidental works." Also, she argues the incidental works approach "takes insufficient account of the reality that many products are, to a significant extent, sold on the basis of their logo or packaging” (at para. 111).

Ibid. at para. 9: Rothstein J. refuses to adopt a purposive interpretation that is not "rooted in the words of the Act" and would constitute reading words into the legislation that is at odds with Parliament's intent, which in his view allows concurrent protection. At para. 10 he states:

Parliament adopted s. 64 of the current Act, which excludes certain functional articles from copyright protection, but affirms that copyright shall subsist in "a trade-mark or representation thereof or a label”. Parliament enacted this provision after having turned its mind to the possibility of overlap between trade-mark and copyright law. Were the Court to hold that the Kraft labels cannot be subjects of trade-mark and copyright concurrently, we would be substituting a different policy preference from that chosen by Parliament.

Ibid. at para. 12 .

Ibid. at para. 13, quoting Kirkbi, supra note 4 at para. 37, LeBel J. 
however, reconcile the interpretation taken in Kirkbi, which in fact lacked a statutory basis, and his strict adherence to statutory language in this case. ${ }^{91}$

\section{b. Nature of the Territorial Interest Transferred}

The other issue on appeal in this case was whether an action for secondary infringement could succeed under s. 27(2)(e) of the CA. Section 27(2)(e) grounds infringement on a hypothetical basis, that is, importing for the purpose of sale, distribution, or trade "a copy of a work ... that the person knows ... would infringe copyright if it had been made in Canada by the person who made it."92 The hypothetical basis for infringement was intended to effect segregated territorial market rights in copyrighted works. As Rothstein J. explained:

\footnotetext{
The apparent purpose of s. 27(2)(e) is to give Canadian copyright holders an added layer of protection where the Canadian copyright holder does not hold copyright in that work in foreign jurisdictions. Section 27(2)(e) protects Canadian copyright holders against “parallel importation” by deeming an infringement of copyright even where the imported works did not infringe copyright laws in the country in which they were made. Without s. 27(2)(e), the foreign copyright holder who could manufacture the work more cheaply abroad could flood the Canadian market for the work, thereby rendering the Canadian copyright worthless. ${ }^{93}$
}

The question becomes, in this case, whether the transferor (KFB or KFS) maintained a residual interest in the copyright (not actionable) or the copyright was transferred in its entirety to the transferee KCI (actionable). Specifically, was there a substantive difference between an assignment and an exclusive licence of a copyright such that the latter retained a residual ownership interest for the licensor? If a residual ownership interest remained with the licensor, then she could not be liable for infringement under s. 27(2)(e).

Looking at the scheme of the statute, Rothstein J. discovered a qualitative distinction between an exclusive licence and an assignment under the $C A .{ }^{94}$ According to him, there was nothing in the Act that displaced the common law rule that a licence was not a transfer of property rights. ${ }^{95}$ Justice Rothstein, however, ran into trouble with the wording of s. 2.7 that defined "exclusive licence" as "an authorization to do any act that is subject to copyright to the exclusion of all others including the copyright owner."

On first impression, we might reasonably think that an exclusive licence does in fact create property-like rights against the copyright owner who, like others, is excluded from use

$91 \quad$ Here I am referring to the application of functionality doctrine to unregistered trademarks in light of s. 13(2), TMA, supra note 63. It should be noted that Rothstein J. was not a member of the Supreme Court at the time of Kirkbi, ibid..

92 Supra note 1 at para. 20 [emphasis in original], citing CA, supra note 39, s. 27(2)(e). To maintain an action for secondary infringement requires that three elements be satisfied: “(1) a primary infringement; (2) the secondary infringer should have known that he or she was dealing with a product of infringement; and (3) the secondary infringer sold, distributed or exposed for sale the infringing goods" (at para. 19). Primary infringement in this case is premised on a hypothetical basis.

$93 \quad$ Kraft, ibid. at para. 21.

$94 \quad$ Ibid. at para. 16: "Parliament intended to provide copyright owners with two qualitatively different mechanisms by which to transfer their interests in whole or in part."

$95 \quad$ Ibid. at paras. 27-28.

$96 \quad$ Ibid. at para. 32 [emphasis added], citing CA, supra note 39, s. 2.7. 
of the copyright. However, Rothstein J. honed in on the word “authorization” which connotes that ownership still resides with the licensor. ${ }^{97}$ This interpretation was buttressed, in Rothstein J.'s view, by s. 36(2) which requires an exclusive licensee to join the owner of the copyright as party to infringement proceedings. ${ }^{98}$ This suggests that "the exclusive licensee does not have a full property interest in the copyright." "J99 Justice Rothstein then had to clear the hurdle set up by Robertson $v$. Thomson Corp. ${ }^{100}$ in which it was held that the "grant of an interest" (which includes an exclusive licence) in ss. 13(4) and 13(7) means the "grant of a property interest." 101 However, this property right was limited, according to Rothstein J., such that a grant of an exclusive licence was "not a complete assignment of copyright. The owner-licensor retains a residual ownership interest in the copyright."102

Justice Abella disagreed with Rothstein J.'s distinction between exclusive licensors and assignors for the purposes of s. 27(2)(e). An exclusive licensee receives a proprietary interest to the copyright under the Act which can be asserted by the licensee against the owner under s. 36(1). ${ }^{103}$ She reasoned that

[a]n exclusive licence which did not prevent others, including the owner-licensor, from performing the acts addressed in the licensing agreement, would no longer be exclusive. It would also render meaningless the statutory definition found in s. 2.7 of an exclusive licensee as the holder of rights "to the exclusion of all others including the copyright owner., ${ }^{104}$

Justice Abella acknowledged that the scope of the interest involved would depend on the terms of the agreement which, in this case, gave the licensee "the sole and exclusive right and license.” ${ }^{105}$ It is therefore possible under the Act for an exclusive licensee to sue the copyright holder for infringing exclusive use under the terms of the agreement, and thus grounds for secondary infringement under s. 27(2)(e) are made out.

\section{c. The Nature of the Interpretive Dilemmas}

On the issue of concurrent trademark and copyright protection, a majority of the Court adopted a literal understanding of s. 64, without further inquiry as to the purpose of the

Kraft, ibid.

Ibid. at para. 33. Furthermore, s. 13(5) is explicit in attributing ownership rights in partial assignments, though the Act says no such thing with respect to exclusive licensees (at paras. 29-30).

Ibid. at para. 33.

2006 SCC 43, [2006] 2 S.C.R. 363 at para. 56 [Robertson].

Kraft, supra note 1 at para. 36: but this case does not "delineate the precise scope" of the property interest.

Ibid. at para. 37. Further, since an exclusive licensee cannot sue the residual ownership of the copyright in Canada under s. 27(2)(e), the only remedy that KCI would have against the licensors is breach of contract (at para. 49).

Ibid. at paras. 118-19: The argument, in her view, is supported by the language of ss. 13(7) and 36(1) as well as the holding in Robertson, supra note 100. At para. 126, Abella J. minimizes the importance of s. 13(5). At para. 75, Bastarache J. expresses agreement with Abella J. on the transfer issue: an exclusive licence is a "sole and exclusive right" to copyright which can be enforced under s. 36(1). As such, hypothetical infringement, and therefore primary infringement, can be made out. Ibid. at para. 127 [emphasis in original].

Ibid. at para. 122. 
provision or its awkward placement in connection with industrial designs. ${ }^{106}$ Justice Bastarache employed a purposive analysis to read down a literal application of s. 64. It is noteworthy as well that Bastarache J. arrived at "incidental works" by referencing the purposes of copyright protection as well as prior Supreme Court jurisprudence which limited IPRs on the basis of purposive considerations. Norms of intellectual property law, developed in prior case law, were thus used to help resolve a difficult case.

The legislative scheme offers an ambiguous answer to the issue of the nature of the territorial interests transferred. In particular, there is inconsistency between s. 2.7 which appears to convey property-like rights through an exclusive licence and the requirement under s. 36 that an exclusive licensee joins the copyright owner as a party to infringement proceedings. ${ }^{107}$ The two judgments on this issue sided either with s. 2.7 or s. 36, but did not adequately account for the contrary indication of the other section. Whereas in Kirkbi, the TMA conveyed a clear (though perhaps unfortunate) answer, a purposive analysis here revealed a thoroughly ambiguous answer.

\section{SUMMATION}

Gleaning meaning from statutory language is an inherently interpretative exercise. ${ }^{108}$ Ardent formalists may tell us otherwise, though we know that words out of context can give rise to multiple meanings; even in context, there may be ambiguity of meaning in connection with application to the facts at hand. The Théberge case offers a prime example of the latter scenario where the meaning of the right to produce and reproduce was entirely unclear in its application to the facts. Courts may, as in Théberge, resolve such uncertainties with reference to the statutory purpose, though this appears to be an inexact tool. Courts may also, as in Kirkbi, use the statute's purpose to override the relatively clear wording and scheme of a statute in order to avoid an absurd result. Such an interpretation, however, demonstrates the excesses of the purposive approach. Whereas the statute's purpose was determinative in both Théberge and Kirkbi, the majority in Kraft sided with a literal understanding of s. 64(3) of the $C A$. Purpose was used as a judicial override of literal language in one case, but not in another. On the whole, these cases reveal an erratic approach to purposive analysis. In the next two sections, I will begin to construct a new way of approaching statutory interpretation, by building on theoretical understandings of statutes and their interpretation.

\section{THEORETICAL UNDERSTANDINGS OF STATUTES AND THEIR INTERPRETATION}

Probative insights concerning the nature of statutes and their interpretation are offered by some of the leading legal philosophers of the twentieth century. Hart posits that while we can identify legal rules emanating from accepted sources, this does not mean that these rules are

Strictly speaking, the Court adopted the view that Parliament intended concurrent protection, though this interpretation was rooted in a literal understanding of the words of the $C A$, supra note 39 , in particular s. 64 .

The schematic interpretation of s. 13(5) by Rothstein J. also favours this interpretation.

See Guido Calabresi, A Common Law for the Age of Statutes (Cambridge, Mass.: Harvard University Press, 1982) at 31: statutory interpretation "involves an almost unavoidable judicial task. Words do not interpret themselves.” Nor, maintains Calabresi, is any one interpretation "manifestly right.” 
necessarily self-applying. In novel cases, courts have discretion to determine the meaning of a rule by considering the interests involved. Natural law theorists like Fuller and Dworkin, on the other hand, focus on uncovering the current purposes of law and the contemporary context in which the law operates. In this sense, natural law theories tend to discount the distant hand of the past in favour of these dynamic considerations. ${ }^{109}$ While not a philosopher of jurisprudence, I include here the important work by Dickerson, whose book, The Interpretation and Application of Statutes ${ }^{110}$ explicates the manner in which we should understand meaning from statutes.

\section{A. H.L.A. HART}

Hart was critical of the formalist conception of self-applying statutory law insofar as general expressions may often be indeterminate in meaning. To be sure, there are "core cases" which are clearly embraced by general expressions. ${ }^{111}$ For example, "no vehicles in the park" clearly applies to motor cars. ${ }^{112}$ However, the general guidance of language faces limits such that it is not clear whether or not bicycles, airplanes, and roller skates are also "vehicles."113 These doubtful cases are resolved by a determination of whether the case "resembles [the core case] 'sufficiently' in 'relevant' respects."114

Our inability to unambiguously regulate in advance reflects two handicaps, according to Hart. First, there is ignorance of fact, meaning that human affairs are comprised of a nonfinite number of features which may combine in a multitude of ways. ${ }^{115}$ Second, the inability to foresee all possible combination of circumstances "brings with it a relative indeterminacy of aim." 116 So, our purpose of enacting a rule prohibiting vehicles in the park may initially be to ensure peace and quiet in the park, but when doubtful cases arise that we did not envisage (for example, a toy motor car electrically propelled), suddenly our aim becomes

Graham, supra note 35 at 31: dynamic approaches to statutory interpretation paid heed to "contemporary ideals, with little or no attention paid to the legislator's intent.” The statute, however, "may evolve in ways that go against the initial intent of the legislation's drafters" (at 32 [emphasis in original]). The benefits of this approach are that it acknowledges "the interplay between the interpretation of a law and its application" (at 37) and can achieve substantive justice in individual cases (at 39). Its problems are that law becomes more unpredictable and more subjective in the sense of giving judges more discretion (at 42).

Reed Dickerson, The Interpretation and Application of Statutes (Boston: Little, Brown and Company, 1975).

Hart varies his terminology between "plain cases," "paradigm cases,” and "standard instances," as well as "core" and "settled" meaning, all of which denote cases which clearly fit within a rule. For consistency, I will use the terms "core cases" and "doubtful cases." H.L.A. Hart, The Concept of Law, 2d ed. (Oxford: Clarendon Press, 1994) at 126 [Hart, Concept]. Ibid. at 127: moreover, cases will fall under the rule when the "resemblances ... can reasonably be defended as both legally relevant and sufficiently close.” In H.L.A. Hart, "Positivism and the Separation of Law and Morals" (1958) 71 Harv. L. Rev. 593 at 607, he characterized these two aspects of language as the "core of settled meaning" and the "penumbra of debatable cases." Hart, Concept, supra note 112 at 127.

115 Ibid. at 128. If this were not so, “[t]his would be a world fit for 'mechanical' jurisprudence," i.e., formalism. 
indeterminate since we must now consider interests that compete with peace and quiet in the park — namely children's recreational pleasure. ${ }^{117}$ Thus:

When the unenvisaged case does arise, we confront the issues at stake and can then settle the question by choosing between the competing interests in the way which best satisfies us. In doing so we shall have rendered more determinate our initial aim, and shall incidentally have settled a question as to the meaning, for the purposes of this rule, of a general word. ${ }^{118}$

As such, Hart embraces a formalistic approach when the facts "fit" within a core of meaning, but acknowledges the need to modify the purposes and meaning of rules when unforeseen cases arise.

Hart's analysis offers important insights into the nature of statutes and their interpretation. Essential to his understanding of statutory interpretation is a dichotomy of core and doubtful cases based on legislative foreseeability, that is, cases which "fit" within a settled core of meaning and those which float on the fringes of meaning. ${ }^{119}$ Where a case is perceived by the court as doubtful, judicial discretion is exercised: courts analogize with core cases as well as consider any unforeseen competing interests that are impacted. Through this process, meaning is fleshed out but also the purpose of the legislation may be modified to account for unforeseen interests that are affected.

The statutory language at issue in Théberge is a doubtful case in the Hartian sense. The core of meaning associated with the right to produce lies within the realm of derivative works, for example, transforming a book into a movie, but whether this right is engaged by changing the work's substrate appears on the fringes of meaning. The court is left to analogize with core cases (which it does not do), as well as balance the interests in play: the copyright holder's interest in receiving just rewards for his creation, the public's right to dissemination of the work, and the assignee's right to value for her purchase. While these interests encompass the very purpose of copyright, the manner in which they are impacted by these novel facts is not foreseeable. The court ultimately concludes that the proper balance of these interests is to favour the purchaser's rights since the copyright holder's legitimate interests are not affected by the changed substrate. In reaching the result, the purpose of the statute — that is, the balance between these competing interests — is clarified.

\section{B. LON L. FULLER}

Fuller takes exception to the characterization of core and penumbral meaning. "The most obvious defect of [Hart's] theory," Fuller points out, "lies in its assumption that problems of interpretation typically turn on the meaning of individual words." ${ }^{20}$ The reality is quite different in two respects. First, meaning is commonly assigned not to individual words but

Ibid. at 129

Ibid.

This characterization appears to be objective in the sense that the interpreter of the statute perceives the settled meaning and thereafter applies it to the facts at hand.

Lon L. Fuller, "Positivism and Fidelity to Law - A Reply to Professor Hart” (1958) 71 Harv. L. Rev. 630 at 662 [Fuller, "Fidelity”]. 
to a sentence, a section, or an entire text. ${ }^{121}$ In the Morality of Law, he elaborates his attack on what he refers to as the "pointer theory of meaning":

This view conceives [legislative intent] to be directed toward individual things, rather than toward general ideas, toward distinct situations of fact rather than toward some significance in human affairs that these situations may share. ${ }^{122}$

In other words, whether facts fit within a rule will depend on whether they share sufficient commonalities with the abstract idea, and not whether they conform with some pre-conceived "core case."

Second, it is not possible to interpret even a single word, much less an entire text, without knowing the purpose of the statute. ${ }^{123}$ To take Hart's "no vehicle in the park" example, if local patriots were to wheel a truck used in World War II on a pedestal, would this qualify as a core case? This example illustrates that meaning of language in a statute cannot be divorced from an inquiry into the purpose that a rule serves. When courts are offered competing interpretations, they must choose the one that is most sensible in connection with its legislative purpose, ${ }^{124}$ and makes the statute "a coherent [and] workable whole."125 Moreover, the purpose of a statute is not static, but through interpretation, courts engage in a process of redefining and clarifying the ends themselves. ${ }^{126}$ As Fuller puts it, courts must "be sufficiently capable of putting [themselves] in the position of those who drafted the rule to know what they thought 'ought to be.' It is in the light of this 'ought' that [they] must decide what the rule 'is.",127

Ibid. at 663

Lon L. Fuller, The Morality of Law (New Haven: Yale University Press, 1964) at 84 [Fuller, Morality, emphasis added]. Rather than missing "obvious targets," statutes are deficient in terms of being "blunt and incomplete" (at 84).

Fuller, "Fidelity," supra note 120 at 664.

Fuller, Morality, supra note 122 at 68. See also Peter R. Teachout, “'Uncreated Conscience’: The Civilizing Force of Fuller's Jurisprudence” in William J. Witteveen \& Wibren van der Burg, eds., Rediscovering Fuller: Essays on Implicit Law and Institutional Design (Amsterdam: Amsterdam University Press, 1999) 229: This will involve understanding and reconciling the complementary and competing purposes found in law and to "consider how these purposes might best be advanced, individually or collectively, in a context of competing policy considerations and practical constraints" (at 252).

Fuller, "Fidelity," supra note 120 at 667. See also Lon L. Fuller, Anatomy of the Law (New York: Frederick A. Praeger, 1968) at 59-60 [Fuller, Anatomy]: to make sense of contradictory statutes, "the judge must of necessity take his guidance from some principle not expressed in the statutes themselves." Fuller, "Fidelity," ibid. at 668.

Ibid. at 666. See also Lon L. Fuller, The Law in Quest of Itself (Boston: Beacon Press, 1940) at 10: "The statute ... is not a segment of being but ... a process of becoming. By being reinterpreted it becomes, by imperceptible degrees, something that it was not originally.” At 8-9, Fuller likens this to the retelling of a story [emphasis in original]:

If I attempt to retell a funny story which I have heard, the story as I tell it will be the product of two

forces: (1) the story as I heard it, the story as it is at the time of its first telling; (2) my conception of the point of the story, in other words, my notion of the story as it ought to be. As I retell the story I make no attempt to estimate exactly the pressure of these two forces, though it is clear that their respective influences may vary.... [The story] is not a hard chunk of reality, but a fluid process, which is as much directed by men's creative impulses, by their conception of the story as it ought to be, as it is by the original event which unlocked those impulses.

In this sense, interpretation does not delineate between "is" and "ought," but both are relevant to the interpretive enterprise. 
In the Anatomy of the Law, Fuller emphasizes the centrality of external context, which helps to constitute statutory purpose(s). ${ }^{128}$ The relevant point of controversy in a statutory command "no vehicles allowed" is not what qualifies as a vehicle but what is implicit in the place where the vehicle is not allowed, for example, a park. In other words, implicit in such a statement is a focus on the meaning of the park as an institution in lives of people who are affected by it. Thus, words must be analyzed both in context (the institution of the park) and in connection with the purpose of those words (why should no vehicles be allowed in the park?) in order to determine meaning. As Fuller puts it:

\begin{abstract}
The troublesome cases are in reality resolved not in advance by the legislator, but at the point of application. This means that in applying the statute, the judge or police sergeant must be guided not simply by the words but also by some conception of what is fit and proper to come into the park; conceptions of this sort are implicit in the practices and attitudes of the society of which he is a member.... All this adds up to the conclusion that an important part of the statute in question is not made by the legislator, but grows and develops as an implication of complex practices and attitudes which may themselves be in a state of development or change. ${ }^{129}$
\end{abstract}

The preoccupation with "practices and attitudes" in the above passage is consonant with Sullivan's conception of external context, as an "evolving set of institutions, relationships and cultural assumptions." ${ }^{130}$ It is clear, however, that Fuller places unusual emphasis on this consideration.

Fuller's conception of statutory interpretation as an evolving story that changes in meaning and purpose as cases unfold, and as the external context shapes, is highly dynamic and necessarily places the judge at the centre of the interpretive process. Fuller embraces a more abstract conception of the subject matter to be regulated, to which novel cases may fit depending on their degree of commonality with the abstract conception communicated. He also maintains that words cannot be separated from their purposes or literary and schematic context without leading to poor interpretations.

Considering the concurrent protection issue in Kraft, Fuller might, first of all, discount a literal interpretation of s. 64(3) of the CA. What is the purpose of this provision, he might ask? Is it to permit blanket protection in every context, or is it merely an exception that appears within the narrow confines of s. 64? Fuller, who like Hart was pessimistic about the ability of the legislature to prospectively regulate complex human affairs, might favour the latter interpretation. If that is the case, then we might consider whether copyright protection of brand logos would best serve the purposes of the legislation while remaining practical and relevant to those affected by this interpretation. Here, external context may tip the balance.

Fuller, Anatomy, supra note 125.

129 Ibid. at 59 [emphasis added]. The process of interpreting a statute is not just drawing out what legislators put into it, but adjusting the statute to the implicit demands and values of the society to which it is to be applied. "In this sense it may be said that no enacted law ever comes from its legislator wholly and fully "made." See also Gerald J. Postema "Implicit Law” in Witteveen \& van der Burg, supra note 124, 255 at 258-59 [footnotes omitted]: The successful creation of new rules, according to Fuller's interactionalist account of law, will depend on its reasonableness as "a function of integration of the rule into the network of expectations and interdependent purposes and intentions of the agents involved." 
Societal norms of competition and free trade, which are the mainstays of our current economy and are reflected in international treaties such as the Agreement Establishing the World Trade Organization ${ }^{131}$ and the North American Free Trade Agreement Between the Government of Canada, the Government of Mexico and the Government of the United States, ${ }^{132}$ might be considered "practices and attitudes" relevant to shaping the purpose of copyright law, thus justifying a departure from an overly broad reading of s. 64(3). ${ }^{133}$

\section{RONALD DWORKIN}

In Law's Empire, Dworkin presents his theory of legal interpretation. ${ }^{134}$ For Dworkin, legal rules are to be understood with an "interpretative attitude" meaning that we do not follow rules blindly but appreciate their value as having a purpose. As such, a given rule is not static but is capable of modification or qualification in being "sensitive to its point."135 The interpreter of a legal rule should follow a notional three-step interpretive process. After we identify the relevant law (the pre-interpretive stage), the task falls to discern the main justification of the law in accordance with its fit, that is, being generally consistent with prior practice (the interpretive stage) ${ }^{136}$ The next step (the post-interpretive stage) requires interpretative adjustment such that the rule best serves the justification accepted at the interpretive stage.$^{137}$ In this regard, Dworkin likens interpretation to a chain novel where each author (in our context, a judge) develops the story the best that she can, as limited by prior development of the story (a string of precedent). A further aspiration is that of adjudicative integrity: judges should treat the law as a coherent set of principles and in so doing, interpret the law to "find implicit standards between and beneath the explicit ones." 138 Integrity thus requires that judges interpret the law as if it were created by "a single author — the community personified — expressing a coherent conception of justice and fairness.”139

15 April 1994, 1867 U.N.T.S. I-31874 (entered into force in Canada 1 January 1995) [WTO].

17 December 1992, Can. T.S. 1994 No. 2, 32 I.L.M. 289 (entered into force 1 January 1994).

While nothing in our international trade agreements explicitly prohibits the use of intellectual property by private actors to undermine free trade, it does seem to violate the spirit of these trade pacts. See e.g. Agreement on Trade-Related Aspects of Intellectual Property Rights, Annex 1C to the WTO, supra note 131 [Annex 1C], preamble (first recital): “Desiring ... to ensure that measures and procedures to enforce intellectual property rights do not themselves become barriers to legitimate trade.” Article 8(2) enables states to adopt “[a]ppropriate measures ... needed to prevent the abuse of intellectual property rights by right holders or the resort to practices which unreasonably restrain trade.” These provisions convey that an important purpose of Annex 1C is to ensure that IPRs are not used to illegitimately inhibit trade. While siding with a literal understanding of s. 64(3), Fish J. expressed dismay about the strategic use of IPRs to undermine competition in the marketplace. Specifically, he had "grave doubt whether the law governing the protection of IPRs in Canada can be transformed in this way into an instrument of trade control not contemplated by the Copyright Act”: Kraft, supra note 1 at para. 56.

Ronald Dworkin, Law's Empire (Cambridge, Mass.: Harvard University Press, 1986) [Dworkin, Empire].

Ibid. at 47. This refers to the interaction between object (say a rule) and its purpose, the latter informing the former to make it the best it can possibly be (at 52-53).

Ibid. at 245: precedent need not be strictly adhered to, i.e., a new interpretation need not fit exactly with all elements of prior cases, but it should have general explanatory power for what came before.

Ibid. at 66.

Ibid. at 217.

Ibid. at 225. Integrity is understood in the horizontal sense, i.e., "[a] consistency of principle across the range of legal standards that the community now enforces” (at 227). Integrity begins in the present and pursues the past to the extent that the contemporary focus dictates (at 245). While normally, judges would limit their inquiry to narrow areas of the law in issue, the scope of the interpretive exercise can 
In the statutory context, the interpretation process is somewhat modified. Dworkin identifies a special constraint in the chain novel exercise that should apply to the interpretive process: a judge will treat the legislature as an author with "special powers and responsibilities" though she will continue to develop the law as best she can. ${ }^{140}$ The text of the statute, as well as authentic expressions from legislators at the time of enactment, will be highly relevant, though the purposes therein will be amenable to change through the course of time, taking into account "other decisions that Congress [that is, legislators] and the courts have made in the meantime." ${ }^{141}$ More specifically, the judge should understand the purpose of a statute — not as an amalgam of individual intents of legislators — but as political events to which an interpretive attitude is applied consistent with the notion of integrity. ${ }^{142}$ Furthermore,

[i]ntegrity requires him to construct, for each statute he is asked to enforce, some justification that fits and flows through the statute and is, if possible, consistent with other legislation in force. This means he must ask himself which combination of which principles and policies, with which assignments of relative importance when these compete, provides the best case for what the plain words of the statute plainly require. $^{143}$

There remains the question of what Dworkin means by legal principle. In Taking Rights Seriously, ${ }^{144}$ Dworkin distinguishes between rules and principles. Rules operate "in an all-ornothing fashion. If the facts a rule stipulates are given, then either the rule is valid ... or it is not." 145 Principles do not operate in an all-or-nothing fashion, nor do they explicate the conditions of their application; rather, they offer a reason to argue in one direction but without necessitating a particular decision. ${ }^{146}$ As an example, Dworkin presents the case of Riggs v. Palmer ${ }^{147}$ in which the Court was faced with a grandson seeking to inherit from a validly enacted will made by the grandfather whom the grandson murdered. Since this was a validly enacted will according to statute (and further there was no mention that a beneficiary could not inherit as a result of murdering a testator), a straightforward application of the rule should have permitted the grandson to inherit. Yet, the Court found that it is a fundamental maxim of the common law, as found in contract and property law, that no one should profit from her own wrongdoing; as such, the grandson was denied the inheritance. ${ }^{148}$

In the above example, we can see that rules fit within the positivist account of law - as emanating from the legislature as an accepted source of rules — but that principles have no such pedigree:

"fan out" to related areas of the law or even further.

Ibid. at 313.

Ibid. at 349 .

Ibid. at 316 .

Ibid. at 338 [footnotes omitted].

Ronald Dworkin, Taking Rights Seriously (Cambridge, Mass.: Harvard University Press, 1977) [Dworkin, Rights].

Ibid. at 24. For example, if a legal rule stipulates "no parking for more than 30 minutes," then a car which stays longer has violated that rule.

Ibid. at 26. Further, a distinction is drawn between policy - a consequential concern for developing the law to achieve some economic, political, or social goal - and principle - which is to be observed "because it is a requirement of justice or fairness or some other dimension of morality" (at 22). 115 N.Y. 506 (1889) (C.A.) [Riggs].

Dworkin, Rights, supra note 144 at 23. 
Instead, we make a case for a principle, and for its weight, by appealing to an amalgam of practice and other principles in which the implications of legislative and judicial history figure along with appeals to community practices and understandings. There is no litmus paper for testing the soundness of such a case — it is a matter of judgment, and reasonable men may disagree. ${ }^{149}$

But how do we know when, as in Riggs, a rule should be changed by a principle? Dworkin's answer in Law's Empire, when he revisits this question is: "[i]t is only because we think the case for excluding murderers from a general statute of wills is a strong one, sanctioned by principles elsewhere respected in the law, that we find the statute unclear on that issue.”150

Dworkin's approach borrows, and elaborates upon, Fuller's story analogy positing the evolution of meaning through the fit of rules from prior case law and their appeal with evolving statutory purpose(s). The emphasis on precedent and plain meaning are restraining elements. The concept of integrity suggests that the interpretive enterprise has regard to the coherence of the law writ whole (including legal principle that runs through the law), as well as authentic clarifications of intent by political actors.

Dworkin's approach arguably finds resonance with Bastarache J.'s opinion in Kraft. Justice Bastarache denies copyright protection for the chocolate bar logos in favour of what may be characterized as principles of intellectual property case law, that is, the separation principle and legitimate economic rights. These principles acted as a convincing argument which modified the application of a rule. Like Riggs, the rule (or at least absence of clear prohibition) permitting the grandson to inherit despite his wrongdoing (or that copyright and trademark may subsist together) gives way to nullification of the right in the face of the principle "no man shall profit from his wrongdoing" (copyright that is incidental will not be recognized based on the separation thesis and the legitimate economic rights of the copyright holder). ${ }^{151}$ I will argue at the conclusion of this article, that there is no meaningful difference between policy, principle, and purpose, at least in terms of the standard applied by Bastarache J., to resolve this interpretive dilemma.

\section{REED DICKERSON}

In a thoughtful treatment of the subject, Dickerson presents an interesting two-tiered methodology to statutory interpretation. ${ }^{152}$ According to Dickerson, the first function of a

Ibid. at 36. He also states at 40: it is not possible to identify with any accuracy the institutional support needed to invoke a principle to assign a fixed weight. Instead, "[w]e argue for a particular principle by grappling with a whole set of shifting, developing and interacting standards ... about institutional responsibility, statutory interpretation, the persuasive force of various sorts of precedent, the relation of all these to contemporary moral practices, and hosts of other such standards. We could not bolt all of these together into a single 'rule'” (at 40). Dworkin, Empire, supra note 134 at 352 [emphasis in original].

151 Furthermore, Bastarache J.'s effort reflects Dworkin's aspiration that courts employ integrity to ensure the coherence of the law, i.e., through clarifying the interaction between different regimes of intellectual property law. Dworkin's theory is also implicated by Rothstein J.'s explanation of the Robertson, supra note 100 , decision pertaining to the proprietary nature of an exclusive licence. He effectively reads down the "property" interest as propounded in that case. This may be an example of where the court's interpretation does not adequately fit with precedent and thus, may be a basis for favouring the majority interpretation on this issue, given the ambiguity of statutory meaning. 
court is to "find out what [the legislature] mean[s] and honor the meaning so found." 153 This cognitive function requires that the court first ascertain meaning as it relates to the dispute. If a judge is able to conclude with "reasonable confidence" that a particular "reading of the statute is one that the typical reader views as most probably intended by the legislature," then we may say that he has ascertained the meaning. ${ }^{154}$ Necessarily, this is a matter of individual judgment as it is to be "measured ... by the range of subjective connotations that [the statute] establishes in the mind of the typical reader," which may exceed actual intent of the legislature or any notion of legislative foreseeability. ${ }^{155}$

The concept of connotations is critical to the interpretive exercise; the "connotations of words define their meanings," though these are derivative of general ideas not specific things. ${ }^{156}$ Notice that Dickerson understands meaning in the objective sense, as what the "typical reader" views as the intention of the legislature. This is central to Dickerson's conception of meaning through statutory language:

[W]e are interested in the intended meaning of the author in the sense that the process of communication makes no sense unless some intention can be attributed to him. Intended meaning, therefore, remains the ultimate object of search even though no method has yet been devised by which this meaning can be directly known. Because the author's subjective intent is knowable only through inferences drawn from his use of external signs, and because communication through external signs is possible only by virtue of established conventions, actual subjective intent is knowable, if at all, only by inference from those conventions as conditioned by context. $^{157}$

For communication to be successful, Dickerson maintains, there are certain presumptions the reader must have in mind when reading the statute. The most important of these is that, unless circumstances suggest otherwise, the legislator is presumed to have followed "the established conventions of language, common to him and his audience, in preparing the document in question. It is presumed, more specifically, that he has used his words in senses that are normal or usual for the subject to which the statute is addressed." 158 A second presumption is the intention of substantive consistency, that is, one part of a statute does not contradict another part, through which we may infer schematic meaning. ${ }^{159}$ This "not only orients the interpreter but makes possible the acts of induction and deduction by which he

Ibid. at 27 [footnotes omitted].

Ibid. at 23.

Ibid. at 128 .

Ibid. at 36 [footnotes omitted].

Ibid. at 223. To the extent the author deviates from common usage, she risks having the statute interpreted in a manner not intended by her. The conventions of language are presupposed by shared culture, i.e., "[a] pervasive network or grid of concepts presupposed by the language of that culture ... the coordinate fund of habits, knowledge, values, and purposes that are shared by the great bulk of the speech community of which both author and audience are members ... [and] the general fabric of basic knowledge and assumptions, express or tacit, that are shared by the users of the language" (at 106-107 [footnotes omitted]).

159 Ibid. at 224: schematic meaning is also advanced by the presumption that a statute "expresses an immediate, coherent purpose" facilitating "broader or more remote purposes." 
can integrate into a coherent whole what would otherwise be only linguistic miscellany.”160 A third presumption is that an author varies her terminology within a statute meaningfully. ${ }^{161}$

Where a judge is unable to ascertain meaning in this way with confidence, Dickerson proposes that the door opens for the court to exercise a disciplined creative function. ${ }^{162}$ The creative function may be exercised in a variety of scenarios when ascertainable meaning is elusive. ${ }^{163}$ On this last point, Dickerson suggests that the court puts itself in the place of the "reasonable legislature" at the time of statutory enactment. ${ }^{164}$ Reliance of the court on these elements of restraint ensure a disciplined creative function of the judiciary.

Dickerson's most important contribution to interpretation is the manner in which he conceives the reception of statutory meaning. We cannot know the actual intent of the legislator except through the manifest expressions (and reasonably drawn inferences therefrom) of the statute. While this requires work and an interpretive frame of mind, statutes are capable of conveying rich meaning. This occurs through our subjective appreciations of the language employed and schemes implemented through the statute. Language and scheme are deemed meaningful and consistent, through which reasonable (and hopefully intended) connotations are conjured up in the mind of the reader.

\section{E. SUMMATION}

Both Hart and Fuller agree that statutory language is threadbare and incapable of comprehensively regulating human affairs in connection with a subject matter. Both also speak of evolving purposes of legislation to accommodate new interests; while Fuller is more explicit in acknowledging the external context as a prominent consideration, this may be implied in Hart's analysis. There is no doubt that Fuller's approach to interpretation is more explicitly dynamic, particularly in terms of keeping law attuned to the lives of people affected by it. In essence, Dworkin shares Fuller's dynamic conception of statutory interpretation, though the judge's interpretive discretion is narrowed by considerations of precedent and, at least with respect to matters of policy, a measure of deference to legislative intent (which is also conceptualized dynamically). Dworkin's concept of integrity gives special regard to making the law as a whole coherent; thus, courts should have discretion in drawing out and applying principles of law to resolve specific disputes. Finally, Dickerson offers an analytical framework to more precisely gauge legislative intention. By following certain presumptions pertaining to the precision and consistency of language, judges are able to derive richer meaning from otherwise threadbare statutes.

Ibid. [footnotes omitted].

Ibid. at 225, n. 20 and accompanying text. The assumption underlying these presumptions is that there is a single plausible reading of the statute which, of course, may vary depending on the judge.

Ibid. at 26-27.

Ibid. at 238-61. Where the meaning is ambiguous, i.e., there are two or more reasonably plausible interpretive alternatives, Dickerson advocates recourse to legislative history, and when this fails, to "further the manifest legislative purpose as consistently as possible with the statute and rest of the legal order" (at 244).

Ibid. at 243-44. 


\section{A METHODOLOGY OF STATUTORY INTERPRETATION}

Building on the insights of the theorists discussed above, I attempt, in this final section, to propose a methodology of statutory interpretation for the kinds of cases considered in this article. I will begin with a discussion of the competency and legitimacy of courts to interpret statutes, followed by an examination of statutes as communicative devices. I will then propose a methodology for interpreting statutes with specific regard to uncovering legislative intention to resolve novel cases.

\section{A. INSTITUTIONAL LEGITIMACY AND COMPETENCY}

Thomas Jefferson once proposed that all statutes and constitutions should expire after a period of 19 years. ${ }^{165}$ Nothing of the kind happens and, in fact, most statutes are infrequently amended. ${ }^{166}$ Should we care whether courts give effect to the legislative intention behind statutes drafted decades ago and which are not amended due to legislative inertia? ${ }^{167}$ The short answer is that, while we may debate the current democratic legitimacy of old statutes, they are still a better indicator of democratic will than what a particular judge may, in his or her undisciplined discretion, suggest as the best way to resolve an interpretive dilemma. ${ }^{168}$

But if novel cases are such that they are prima facie unforeseeable and not explicitly addressed in the statute, should not the legislature be in the best position to resolve troublesome cases in accordance with democratic will? We might be concerned about politicizing legal rights through such a process. Indeed, the notion of judicial independence is predicated on insulating individual rights against state intrusion. Putting that issue aside, having the legislature determine what it meant in a state offers no particular advantage:

\footnotetext{
The plain fact is that in most cases where doubt can arise as to whether a particular situation is covered by a statute, no intellectual resources are available to the legislature in deciding the question that are not equally available to the judge, who normally has, furthermore, the advantage of more experience in dealing with such questions. $^{169}$
}

It is unlikely that the legislature could explain what it meant in a novel case which prima facie is beyond what the legislature anticipated. Even supposing the legislature does have special knowledge of what was meant by statutory language in connection with a specific dispute, resolution of the case should not turn on what the legislature meant to say but what

Supra note 108 at 59.

Many of the intellectual property statutes in Canada were passed decades ago, with very few amendments since. Since 1921, the CA, supra note 39, has been amended six times: in 1923, 1931, 1970, 1988 , 1993, and 1997. The TMA, supra note 63, has been amended only once, occurring in 1993. Since 1869, the Patent Act, R.S.C. 1985, c. P-4, has been amended eight times, occurring in the years 1872, 1923, 1935, 1969, 1987, 1993, 2004, and 2006.

See supra note 108 at 102: a majoritarian origin that created legislation may no longer exist, yet the statute is not repealed or amended due to inertia.

One could argue that judges are best able to give effect to the current democratic will as opposed to legislation which persists only because of inertia. Rather than the extremes of unfettered judicial discretion on the one hand, and slavish adherence to literal reading on the other, this article argues that the language of legislation can evolve dynamically through a process of analogical reasoning. Fuller, Anatomy, supra note 125 at 18. 
it succeeded in saying. ${ }^{170}$ Thus, interpretation by the legislature presents serious rule of law concerns (politicizing rights, reasonable transparency, and predictability of rules) that are not offset by efficacy gains in decision-making in connection with novel cases.

The tensions underlying debates about proper methods of statutory interpretation are less about proper institutional roles, that is, whether the judicial or legislative branch should "make" law, and more about how to give effect to a discernible legislative intent. It is because statutes are vaguely worded and prospectively drafted in view of paradigmatically conceived scenarios that the judicial role is enhanced through their need to resolve disputes for which no obvious answer is forthcoming from the statute. The demands of the interpretive role in specific cases are such that a court is not required, nor is it competent, to radically overhaul the law. ${ }^{171}$ Still, they are legitimately and competently entrusted to interpret the meaning of statutes to resolve cases before them in accordance with the intent of the legislature. $^{172}$

\section{B. Statutes as Communicative Devices}

Superficially, statutes are threadbare vessels of communication. As both Hart and Fuller describe, statutes attempt to regulate complex subject matter in advance (prospectivity) and in anticipation (foreseeability) of actual events that might arise. Often, the legislature does not even attempt to be comprehensive but instead prescribes rules in vague and sweeping terms, for example, the "right to produce or reproduce a work." As such, statutes do not suggest specific, or even reasonably certain, answers to novel cases which, by definition, are beyond the contemplation of the legislature at the time of enactment. But it is because the legislature acknowledges the inability to regulate unforeseeable kinds of cases that they resort to vague language as a signal to courts to exercise their interpretive function. ${ }^{173}$

Fuller was attuned to both the limitations and possibilities of statutory language. Rather pessimistically, he attacks statutes as both reflecting "diagrammatically conceived situations" and "remote from the actual affairs of men." ${ }^{174}$ But while legislative intention cannot

Ibid.

See supra note 108 at 146: courts are not well situated to do this for the following reasons: they do not have data; not all issues can be addressed in an adversarial setting; there is a need for warning and certainty in some cases; and we do not want to foster legislative abrogation of responsibility.

See ibid. at 96: courts are best equipped to make rational decisions to justify their decisions, to uncover principles of law; to consider the whole fabric of the law; and to develop law incrementally.

Graham, supra note 35 at 126.

Fuller, Anatomy, supra note 125 at 106: “codified law commonly offers a simplified pattern remote from the actual affairs of men. It deals with diagrammatically conceived situations which seldom correspond to actual cases." Further, he contrasts the hollowness of legislative enactment against the richness and nuance of the adjudicative function of courts. Statutory law is prospective in nature and devoid of explicit justification for its provisions. The common law, by contrast, engages actual controversies through which facts are established, competing arguments are considered, and detailed justifications for a ruling are offered, upon which law can be "compared, re-examined and rearticulated." See also Cass R. Sunstein, Legal Reasoning and Political Conflict (Oxford: Oxford University Press, 1996) at 184: "Sometimes it is impossible for good lawmakers to foresee odd applications; as we have seen, life outruns even the most well-considered law. The legislature's power to correct absurd or unjust outcomes after the fact is an unreliable safeguard, since the legislature has many things to worry over, and a particular absurd outcome may not seem sufficiently pressing to claim its attention after the fact.” This, according to Sunstein, is a reason for courts to correct absurd applications of the law. 
realistically be excavated to address specific cases, he suggests we can infer intention to regulate certain kinds of events. Legislative intent is not pointed to specific instances, in other words, but to "general ideas" which share "some significance in human affairs." 175 The abstraction of subject matter which might fall under the rule, therefore, demands interpretation in individual cases and may include that which was unforeseen at the time of enactment.

The interpretive task of the judiciary, however, is merely one side of the process of successfully developing statutory meaning. There is also a responsibility of the legislature to communicate meaningfully to the judiciary. The legislature should be presumed competent to envision foreseeable kinds of events for which it is establishing rules, and to deal with these events in a precise, consistent, and meaningful fashion. ${ }^{176}$ These needs underlie the presumptions that are so crucial to Dickerson's conception of successfully communicating meaning through statutory language. Fuller conceptualizes the critical nature of the reciprocal relationship between legislative drafting and judicial interpretation for the development of law to be successful:

With all its subtleties, the problem of interpretation occupies a sensitive, central position in the internal morality of the law. It reveals, as no other problem can, the cooperative nature of the task of maintaining legality. If the interpreting agent is to preserve a sense of useful mission, the legislature must not impose on him senseless tasks. If the legislative draftsman is to discharge his responsibilities he, in turn, must be able to anticipate rational and relatively stable modes of interpretation. ${ }^{177}$

A reciprocal relationship of expectations and presumptions, therefore, must exist to make the development of statutory meaning a successful endeavour. Legislatures must be careful and conscientious in the art of drafting in order to maximize accurate meaning. For their part, judges must endeavour to extract statutory meaning, using consistent methodologies that seek to uncover legislative intent, to help resolve the case before it.

While severe limitations inhere to the communication of meaning through statutes, discerning legislative intention to resolve novel cases may be maximized by judges being attuned to the language of an entire statute. This demands that legislatures be precise, consistent, and thorough in communicating meaning. Moreover, the intent behind statutory language may be projected into unforeseen cases if we understand techniques, such as vague language, as signals for developing meaning in accordance with terms of a statute. This, however, requires a more detailed methodology, discussed next.

See supra note 122 and accompanying text. See also Dickerson, supra note 110 at 77 who refers to statutes as regulating "classes of events."

This is consonant with the presumption that "[t]he statute ought always to be presumed to be the work of reasonable men pursuing reasonable purposes reasonably, unless the contrary is made unmistakably to appear": Henry M. Hart, Jr. \& Albert M. Sacks, The Legal Process: Basic Problems in the Making and Application of Law, ed. by William N. Eskridge, Jr. \& Philip P. Frickey (Westbury, N.Y.: Foundation Press, 1994) at 1125.

Fuller, Morality, supra note 122 at 91. 


\section{A METHODOLOGY OF STATUTORY INTERPRETATION}

In usual cases, a purposive analysis of a statutory provision will reveal a reasonably clear meaning in relation to the facts at hand. We know, for example, that making copies of a copyrighted book violates the CA because, upon a full reading of the statute, all elements of the purposive analysis mutually reinforce this interpretation. Section 3 rights, including the "right to reproduce the work" is central to a statutory scheme of infringement remedies for copyright owners (context and scheme) as a means of encouraging the creation of expressive works (purpose). Copying a book is the kind of foreseeable case in the contemplation of the legislature when the statute was enacted, that is, statutes regulate paradigmatically conceived scenarios. These cases are so straightforward that they are rarely litigated. When they are, courts do not typically engage in the full purposive analysis since the result (at least for them) is axiomatic. Nonetheless, the best interpretations of a statute convincingly account for all elements of a purposive analysis (ordinary language, context, scheme, and purpose) through reasoned judgment. Courts should apply this principle vigorously and not selectively, that is, explicitly taking into account all factors.

When there is a discernible conflict between elements of a purposive analysis, this usually means either (1) the statute was poorly drafted, or (2) it is a novel case that lies beyond the foreseeable kind of case for which the statute provides. As we saw in the trilogy, courts sidestep recognition of either (1) or (2) as causes of interpretive dilemmas. Consequently, statutory interpretation takes on the appearance of "cherry-picking” between different techniques of statutory construction to arrive at the desired result. Statutory purpose overrides the wording and scheme of the statute in one case (Kirkbi) while a strictly literal approach is adopted in another (Kraft). By acknowledging either (1) or (2) as the cause of an interpretive difficulty, we may respectively assign proper institutional responsibility for resolving the controversy, as well as instill the interpretive process with greater integrity. Specifically, sloppy drafting is to be remedied by the legislature (and not the courts), while judicial interpretation in novel cases occurs on a foundation of legislative intention which is discernible from the terms of the statute.

The intentions of political actors behind legislation are usually an unhelpful guide for resolving interpretive dilemmas that arise in novel cases. ${ }^{178}$ Still, legislative intent can be gleaned from the face of the statute that may assist a court in resolving the dilemma if we are allowed to make certain presumptions about statutory language. ${ }^{179}$ In many cases, legislative

178 Novel cases are prima facie beyond the contemplation of the legislature, so we should not expect any specific intent to be revealed by consulting legislative history. Notwithstanding this fact, there may be cases where one interpretation of an ambiguous or vague provision is more convincing as revealed by a general intent or perhaps a negative intent (what is not included) of the legislature. I thank Stephen F. Ross for bringing this point to my attention. Even then, how reliable are these communications of intention? Eskridge, Jr., Frickey \& Garrett, supra note 12 at 224 highlight the problems of consulting legislative history, including the peril that statements may be made in the heat of the moment or for strategic reasons, which is as equally true in Canada as in the U.S.

Sullivan, supra note 9 at 204, dismisses objections of critics that legislatures cannot have intentions by pointing to the inference-drawing process of communication in context: "People never have direct access to the content of other minds; they are always in the position of inferring what others must have intended based on what was said and the context in which it was said.” See also comments from LaForest J.A. (as he then was): "There is no doubt that the duty of the courts is to give effect to the intention of the Legislature as expressed in the words of the statute” (at 361, citing Re Estabrooks Pontiac Buick Ltd. 
intent is coterminous with a purposive analysis: for example, understanding words in context or the scheme of the Act may reveal a legislative intent to treat subject matter in a certain way. It may also be more than this if we adopt certain presumptions about statutory language. We may infer intent that the legislature is delegating to the court an interpretive exercise through the use of vague language; or that a change in terminology within a statute, or legislative amendment, is meaningful; or that specific interpretive consequences are to be deduced or induced from schematic features of the statute.

We may be assisted by another presumption that helps us gauge legislative intention. A court's sense of whether or not the case before them was a foreseeable kind of case for inclusion under a rule could serve as a critical basis for resolving the interpretive dilemma. Legislative foreseeability, in this regard, should be appreciated in the abstract and not in connection with the specific facts of the case. If facts before the court are unusual or counterintuitive (Kraft) or the statute upon a purposive analysis is ambiguous on the issue (Théberge), we may presume that the legislature did not foresee this kind of case. In these situations, courts may determine whether the novel facts fit within the rule, or are beyond it, by analogizing with paradigm conceptions of the rule as revealed by the statute, prior case law, or subjective connotations elicited in the mind of the judge.

The treatment of novel facts should be considered on the basis of analogizing material similarities and differences with a range of concrete manifestations of the abstract rule. This methodology does not suggest that we know, in advance, the multitude of concrete manifestations captured by a rule. Rather, Fuller and Dickerson more appropriately characterize vague rules as referring to "classes of events" or "general ideas" in the abstract sense. The fine distinction made here is that abstract conceptions of rules are broader in scope than the limited number of concrete applications of the rule that we might imagine. The range of possible fact scenarios that may fit within the "right to produce," in other words, is beyond what we might preconceive and determine to be within a core of meaning. If, however, we understand this right in the abstract, then we are not limiting possible manifestations of the rule.

Notwithstanding this criticism of Hart, his analysis provides a useful heuristic for resolving novel cases. In doubtful cases, Hart claims that courts resolve meaning by analogy, that is, is the doubtful case sufficiently similar in relevant respects with core cases to justify inclusion under the rule? There are two advantages of applying this method to novel cases, particularly in connection with vague rules. First, analogy is the best means available to connect the treatment of novel facts with legislative intent in respect of matters that we know with some certainty were to be included under the rule. Second, reasoning by analogy leads to principled decision-making in the sense that inclusion or exclusion is based on consideration of the kinds of factual features that make the rule relevant to its purpose. Statutory meaning thus develops according to a more disciplined reasoning process as compared with interpretation through a vague and court-divined conception of a statute's general purpose. In the final part of this article, I put this methodology to work in resolving the interpretive dilemmas that arose in the trilogy. For a comparison of this methodology with the actual judgments in these cases, the reader may wish to consult Appendix A. 


\section{Vague Language (ThÉBERGE)}

Statutory language is vague when it is "uncertain in its respective applications to a number of particulars." ${ }^{80}$ We should understand vague language not in connection with specific instances but with ideas of things that we think should be included under the framework, whether or not in specific contemplation or even knowable at the time of enactment. The use of vague or open-textured language, for example, "the right to produce or reproduce," permits the interpreter to embrace a range of fact scenarios without the legislature identifying them as such. The extent of this range is determined by the degree to which the plentitude of possible fact scenarios are analogous to the paradigm cases available to the court. This process of analogizing, which is not dissimilar to common law development, helps to determine whether there are aspects of the novel facts which distinguish it from a range of standard instances available to the court.

In Théberge, for example, interpretive efforts should have focused on "the right to produce.” In the paradigmatic sense, the right to produce is a right to make a derivative work in the first instance. As Normand Tamaro explains by way of example, "the granting to a television broadcaster of a licence to perform the work will not automatically grant the right to produce a recording of the work. The right to produce is independent of the performing right." ${ }^{181}$ We see here an engagement of production (making an entirely new work based on the old work) and medium rights (television to audio-recording) as contemplated under the $C A$. But this still does not answer the question whether changing the substrate rises to the level of a new production, that is, engages the right to produce. However, if we look at specific manifestations of that right in ss. 3(a) to 3(i), we might conclude that the right to produce is more transformative in form, or qualitatively different in the method of communication, than merely changing the substrate. For example, the production right is engaged by making translations of a work, or by converting a dramatic work into a novel or vice versa. ${ }^{182}$ In terms of mode of communication, the right involves communicating by telecommunication. ${ }^{183}$ By analogizing the facts in Théberge with existing rights of production which we know were intended to comprise a copyright holder's bundle of rights, we extrapolate the kinds of rights that should be included according to the intent of the legislature. ${ }^{184}$

The interpretive issue in Théberge should have been resolved through a purposive analysis, specifically with reference to the immediate context of s. 3. Rather unusually in this case, the vagueness of the right in question was supplemented with specific manifestations in the statute. These examples serve as paradigm cases through which the court could have analogized whether changing the substrate of a work engaged the right to produce. In many situations of vague language, however, courts may need to base analogies on prior case law

Supra note 110 at 49 [footnotes omitted].

Normand Tamaro, The 2005 Annotated Copyright Act (Toronto: Thomson Carswell, 2004) at 201.

Supra note 39, ss. 3(1)(b)-(c).

Ibid. s. 3(1)(f).

The extent to which changing the substrate is analogous to these rights of production may be debated, though it at least provides a discernible and principled basis for determining legislative intent in novel cases. 
or their own subjective appreciation of paradigm cases that arise from a purposive analysis of the statute.

\section{SCHEMATIC MEANING (KIRKBI AND KRAFT)}

Meaning extends beyond words and provisions in isolation, and can be gleaned from the scheme of the legislation such that courts can draw reasonable inferences from a coherent legislative framework. The extent to which a fact situation fits within a scheme apparently contemplated under the legislation augurs for its unqualified treatment according to the scheme. Thus in Kirkbi, the legislative scheme unambiguously prescribes differential treatment between registered and unregistered trademarks in respect of the functionality limitation. That utilitarian features may be integral to, but should not form part of, a distinguishing guise is clearly indicated for registered marks under s. 13 (though not for unregistered marks). Is there something novel about the facts in Kirkbi which suggest this was not the kind of case in contemplation of the legislature when it enacted this scheme? We know that the assertion of the product qua product as a trademark is not a point of distinction since the definition of distinguishing guise includes the "shaping of wares."185 It reasonably follows from the language of the statute (utilitarian features, shaping of wares) that the legislature must have foreseen the likelihood of a product, including the shape thereof, as being eligible for both patent and trademarks protection. This suspicion is confirmed by looking at pre-amendment case law where a similar attempt to register a trademark after an unsuccessful patent application was made by a would-be IPRs holder. ${ }^{186}$

The fact that the guise was formerly under patent does not adequately distinguish it from a paradigmatic case involving non-patentable subject matter. The trademark monopoly is coextensive with its use, meaning the monopoly may be unlimited in duration. If we suppose that the Lego block was not patentable in the first place, would the court have denied it protection as an unregistered trademark? Probably it would have since the more compelling rationale is that products qua products should not be subject to a perpetual monopoly either as registered or unregistered marks. The point is that the prior patent factor is quite irrelevant to the reality that unregistered trademarks under the TMA are not subject to a functionality limitation and thus are eligible for a perpetual monopoly. While seemingly unpalatable from a policy perspective (presuming that a perpetual monopoly of unregistered marks is undesirable based on competition concerns), it is for the legislature, and not the courts, to alter this clear scheme of rights.

In Kraft, by contrast, it should be presumed that the relationship of rights between the owner of a copyright and a licensee/assignee in respect of territorial copyright is a paradigmatic situation. This is a common type of occurrence for which there is every indication, especially in light of the hypothetical infringement rule in s. 27(2)(e), that the legislature addressed its mind to the issue. Notwithstanding this, the statute is internally inconsistent on the interpretive issue. The legislature has unsuccessfully communicated its intention as to whether or not an exclusive licence for territorial copyright exhausts the 
owner's property right in that copyright. In these situations, as in cases where we can presume only an indirect legislative intent (discussed next), courts are left to resolve the dilemma with reference to the statute's purpose, external context, and relevant principles of law.

\section{INDIRECT LEGISLATIVE INTENT (KRAFT)}

The interpretive dilemma concerning concurrent protection in Kraft presents us with a unique statutory interpretation issue: does s. 64(3) indicate an intention by Parliament to permit concurrent copyright and trademark in all instances? It is doubtful that s. 64(3), which appears as an exception to a provision permitting infringement of copyrightable designs, implies as much. A strong argument can be made that we should not extrapolate across the board concurrent protection from this limited exception. Even without s. 64(3), a different argument could still be made: that which is not prohibited is allowed; in other words, there is nothing preventing separate regimes of protection even in the absence of s. 64(3).

It is better to understand this issue from the perspective of what we can presume the legislature contemplated when it permitted (or at least did not prohibit) potentially overlapping regimes copyright and trademark protection. We may presume that the legislature intended that copyright and trademark could co-exist in the same work/mark. For example, the representation of Mickey Mouse is a copyrightable expression in a TV cartoon context, and is also eligible for trademark on a brochure for movies as identifying of the Disney Corporation. Ipso facto, we do not necessarily presume that copyright or trademark would subsist in a context more appropriately the domain of the other, that is, by asserting trademark over the cartoon qua cartoon, and copyright over a brand logo qua brand logo. There is no reason to believe that the legislature addressed its mind to this counterintuitive proposition. Even if that is contested, we are on safe ground in presuming that the legislature did not intend to permit copyright to be asserted in a trademark context as a means of blocking otherwise legitimate trade. The majority's literal reading of s. 64(3) gives too much credit to the ability of the legislature to foresee this kind of case from arising.

In non-paradigmatic cases for which there is no discernible intention from the legislature, the court's creative function is to resolve the interpretive dilemma the best that it can. Courts should weigh competing interpretations for their ability to give effect to the purpose of the statute, as well as the efficacy of their application in the external context. Which rule works best, in other words, in connection with those affected by it? Courts may also be informed by any relevant principles of law that may, as Dworkin advises, offer a reason to deviate from a rule. The facts in Kraft on this issue are non-paradigmatic in that they fall outside a standard instance where both copyright and trademark would subsist in the same work. Justice Bastarache, therefore, was justified in reading down copyright protection in view of the statute's purpose, though he may have buttressed this argument through a consideration of external context. ${ }^{187}$

187 While not formally binding, norms of free trade and competition leading to reduced consumer prices have become deeply ingrained in Canadian society: see Annex 1C, supra note 133. 
Special consideration must be made to Bastarache J.'s invocation of “principles” of intellectual property law which supported his reasoning in Kraft. Courts are best equipped, in cases where there is absence of direct legislative intent, to make sense of the fabric of the law and thus should be allowed leeway to consider principles of law that may help resolve interpretive dilemmas and contribute to coherence of the law. While this is so, Bastarache J.'s reasoning in Kraft reveals no meaningful distinction between policy, purpose, and principle. ${ }^{188}$ The principles invoked in these cases are an amalgam of court declarations of the purposes of regimes of intellectual property law. Moreover, a consideration of relative merits of competing interpretations to resolve individual cases, in view of the external context of their application, may have policy implications. This is not to suggest that there is no difference, only that purpose, principle, and policy, both individually and collectively, pointed to the same interpretive result.

\section{CONCLUSION}

This article has exposed the Supreme Court of Canada's approaches to statutory interpretation as both inconsistent and, at times, excessive. In fairness, courts are often placed in the unenviable position of having to remedy sloppy drafting of the legislature through their interpretations. We can expect incoherent approaches to statutory interpretation to continue, however, until such time as legislatures and courts better conceptualize their institutional roles and responsibilities. This article has argued for a particular understanding of these institutional dimensions and, even more so, a methodology to instill a measure of integrity to process of statutory interpretation. We derive meaning from the language and general framework of a statute through which we understand the kinds of cases anticipated, and those which were not. Measuring new cases against our conception of what was foreseen in terms of paradigm cases connects the interpretation process to legislative intent. As such, we can transform the apparent weakness of paradigmatically conceived statute-making into a principled basis for developing statutory meaning through reasoned analogy.

The status of legal principle and its distinction from policy is a matter of some debate. Sunstein views legal principles in two ways. First, they may serve as justifications for legal rules which, somewhat ironically, can be used to support exceptions to rules. For example, safety is the principle behind a speed limit, though this principle may justify an exception for police performing their duties. Second, principles may be understood in a different and "mysterious" sense as factors that influence decisionmaking - "they bear on cases without disposing of them." See Sunstein, supra note 174 at 30-31. 
Appendix A

\begin{tabular}{|c|c|c|c|}
\hline Issue & Majority & Dissent & Analogizing with Paradigm Cases \\
\hline $\begin{array}{l}\text { “right to produce or } \\
\text { reproduce” } \\
\text { Théberge v. Galerie d'Art du } \\
\text { Petit Champlain, } 2002 \text { SCC } \\
\text { 34, [2002] } 2 \text { S.C.R. } 336 .\end{array}$ & $\begin{array}{l}\text { Purpose } \\
\text { resolves } \\
\text { unclear } \\
\text { meaning }\end{array}$ & $\begin{array}{l}\text { Incomplete } \\
\text { contextual } \\
\text { analysis } \\
\text { resolves } \\
\text { unclear } \\
\text { meaning }\end{array}$ & $\begin{array}{l}\text { Section } 3 \text { explicates the kinds of } \\
\text { production rights protected: analogy } \\
\text { indicates that right intended to be } \\
\text { more transformative in medium or } \\
\text { mode of communication than mere } \\
\text { changing of the poster substrate. }\end{array}$ \\
\hline $\begin{array}{l}\text { Does functionality apply to } \\
\text { unregistered trademarks? } \\
\text { Kirkbi AG v. Ritvik Holdings, } \\
2005 \text { SCC 65, [2005] 3 S.C.R. } \\
302 .\end{array}$ & $\begin{array}{l}\text { Purpose } \\
\text { overrides } \\
\text { legislative } \\
\text { scheme }\end{array}$ & None & $\begin{array}{l}\text { Clear regime of rights indicated. } \\
\text { Statute specifies that guise includes } \\
\text { "shaping of wares" and prohibits } \\
\text { functionality for registered marks } \\
\text { only. That guise may be patentable is } \\
\text { foreseeable and, in any event, does } \\
\text { not distinguish case from paradigm } \\
\text { cases. }\end{array}$ \\
\hline $\begin{array}{l}\text { Whether copyright and } \\
\text { trademark can subsist in the } \\
\text { same work } \\
\text { Euro-Excellence v. Kraft } \\
\text { Canada, } 2007 \text { SCC 37, [2007] } \\
\text { 3 S.C.R. } 20 \text { [Kraft] }\end{array}$ & $\begin{array}{l}\text { Literal } \\
\text { reading of } \\
\text { s. } 64(3)\end{array}$ & $\begin{array}{l}\text { Purpose of } \\
\text { copyright } \\
\text { overrides } \\
\text { literal reading } \\
\text { of } \\
\text { s. } 64(3)\end{array}$ & $\begin{array}{l}\text { Copyright in trademark context to } \\
\text { block legitimate trade beyond } \\
\text { contemplation of the legislature, as } \\
\text { compared with paradigmatic } \\
\text { conception of concurrent protection. } \\
\text { Resolve by considering purpose and } \\
\text { external context. }\end{array}$ \\
\hline $\begin{array}{l}\text { Nature of the interest } \\
\text { transferred } \\
\text { Kraft }\end{array}$ & $\begin{array}{l}\text { Schematic/ } \\
\text { Contextual: } \\
\text { no residual } \\
\text { interest of } \\
\text { owner }\end{array}$ & $\begin{array}{l}\text { Schematic/ } \\
\text { Contextual: } \\
\text { residual } \\
\text { interest of } \\
\text { owner }\end{array}$ & $\begin{array}{l}\text { This kind of situation foreseeable, for } \\
\text { example, hypothetical infringement } \\
\text { rule. } \\
\text { Statute is inconsistent, leading to two } \\
\text { plausible interpretations when statute } \\
\text { is read as a whole } \\
\text { Resolve by considering legislative } \\
\text { purpose and external context }\end{array}$ \\
\hline
\end{tabular}

